\title{
The Implication of Reactive Oxygen Species and Antioxidants in Knee Osteoarthritis
}

\author{
Nicoleta Bianca Tudorachi ${ }^{1}$ (D), Eugenia Eftimie Totu ${ }^{2, *}$, Adrian Fifere ${ }^{3, *}$, Valeriu Ardeleanu ${ }^{1}$, Veronica Mocanu ${ }^{4}(\mathbb{D}$, \\ Cornelia Mircea ${ }^{4}$ (D) Ibrahim Isildak ${ }^{5}$ (D) , Katarina Smilkov ${ }^{6}$ id and Elena Mihaela Cărăuşu ${ }^{7}$
}

1 Faculty of Medicine, “Ovidius” University of Constanța, Mamaia Boulevard 124, 900527 Constanța, Romania; nicoletatudorachi@gmail.com (N.B.T.); valeriu.ardeleanu@gmail.com (V.A.)

2 Faculty of Applied Chemistry and Material Science, University Politehnica of Bucharest, 1-5 Polizu Street, 011061 Bucharest, Romania

3 Centre of Advanced Research in Bionanoconjugates and Biopolymers Department, "Petru Poni" Institute of Macromolecular Chemistry, 41A Grigore Ghica Voda Alley, 700487 Iasi, Romania

4 Faculty of Pharmacy, Grigore T. Popa University of Medicine and Pharmacy Iasi, 700115 Iasi, Romania; veronica.mocanu@gmail.com (V.M.); cornelia.mircea@umfiasi.ro (C.M.)

5 Faculty of Chemistry-Metallurgy, Department of Bioengineering, Yildiz Technical University, Istanbul 34220, Turkey; iisildak@gmail.com

6 Faculty of Medical Sciences, Division of Pharmacy, Department of Applied Pharmacy, Goce Delcev University, Krste Misirkov Street, No. 10-A, 2000 Stip, North Macedonia; katarina.smilkov@ugd.edu.mk

7 Faculty of Dental Medicine, "Grigore T. Popa” University of Medicine and Pharmacy, "Nicolae Leon" Building, 13 Grigore Ghica Street, 700259 Iasi, Romania; mihaelaelenacarausu@gmail.com

* Correspondence: eugenia.totu@upb.ro (E.E.T.); fifere@icmpp.ro (A.F.)

Citation: Tudorachi, N.B.; Totu, E.E.; Fifere, A.; Ardeleanu, V.; Mocanu, V.; Mircea, C.; Isildak, I.; Smilkov, K.; Cărăuşu, E.M. The Implication of Reactive Oxygen Species and Antioxidants in Knee Osteoarthritis Antioxidants 2021, 10, 985. https:// doi.org/10.3390/antiox10060985

Academic Editor: Maria-Jose Alcaraz

Received: 16 May 2021

Accepted: 17 June 2021

Published: 21 June 2021

Publisher's Note: MDPI stays neutral with regard to jurisdictional claims in published maps and institutional affiliations.

Copyright: (c) 2021 by the authors. Licensee MDPI, Basel, Switzerland. This article is an open access article distributed under the terms and conditions of the Creative Commons Attribution (CC BY) license (https:/ / creativecommons.org/licenses/by/ $4.0 /)$.

\begin{abstract}
Knee osteoarthritis (KOA) is a chronic multifactorial pathology and a current and essential challenge for public health, with a negative impact on the geriatric patient's quality of life. The pathophysiology is not fully known; therefore, no specific treatment has been found to date. The increase in the number of newly diagnosed cases of KOA is worrying, and it is essential to reduce the risk factors and detect those with a protective role in this context. The destructive effects of free radicals consist of the acceleration of chondrosenescence and apoptosis. Among other risk factors, the influence of redox imbalance on the homeostasis of the osteoarticular system is highlighted. The evolution of KOA can be correlated with oxidative stress markers or antioxidant status. These factors reveal the importance of maintaining a redox balance for the joints and the whole body's health, emphasizing the importance of an individualized therapeutic approach based on antioxidant effects. This paper aims to present an updated picture of the implications of reactive oxygen species (ROS) in KOA from pathophysiological and biochemical perspectives, focusing on antioxidant systems that could establish the premises for appropriate treatment to restore the redox balance and improve the condition of patients with KOA.
\end{abstract}

Keywords: oxidative stress; ROS; antioxidants; pathophysiology; KOA; cellular senescence; apoptosis

\section{Introduction}

Knee osteoarthritis (KOA) is known as a chronic degenerative disease and a significant public health issue worldwide; the economic burden associated with it rises with population aging in most countries [1]. It is one of the prevalent causes of disability, extensively affecting patients' quality of life [2]. Whereas KOA used to be considered a geriatric pathology, lately, it has been recorded among ever-younger patients [3]. Moreover, KOA prevalence has increased considerably in older adults (persons aged 60 and over) [4]. During the last decade, an increased number of newly diagnosed cases has been recorded [5]. In addition, by 2030, the number of arthroplasties is estimated to increase by $276 \%$ [6,7], while the number of specialty consults is expected to rise by $15.7 \%$ in 2032 , compared to 2012 [8]. 
The role of oxidative stress in KOA physiopathology is still a topic of analysis. The effects of free radicals on cartilage components involve cellular senescence and apoptosis, while their existence is conditioned by endogenous or exogenous factors characterized by specific chemical and physical parameters. The most important chemical parameters determining or marking a particular physiological process are $\mathrm{pH}$ and the redox state. These parameters have different values as a function of the analyzed organ or tissue within the body, the living conditions, or the existence of certain pathologies $[9,10]$.

Along with other risk factors, all these alterations favor the onset and progression of $\mathrm{KOA}$ and impose a series of blood tests enabling the identification of free radicals and serum antioxidants levels for tailoring a personalized therapeutic approach that could include sources of antioxidants. In this context, it is essential to develop appropriate strategies and identify the appropriate prevention solutions by discovering and reducing alterable risk factors [9]. For instance, weight control, active life, and a diet rich in antioxidants, as well as antioxidant therapies, are essential pillars of KOA prevention. The aim of this review is to highlight the influence of ROS and antioxidants in KOA among older adults, analyzed from pathophysiological and biochemical perspectives. The authors performed an electronic literature survey in the PubMed, EMBASE, Web of Science, ScienceDirect, and Google Scholar databases using keyword search terms. The investigation was completed with a manual search. In this review, only published English-language papers were considered. The present work includes cohort studies, randomized, double-blind, placebo-controlled clinical trials, meta-analyses, and reviewed studies.

\section{ROS and Antioxidants}

ROS comprise species with unpaired electrons, also called paramagnetic, such as free radicals, diamagnetic species with oxidant properties, or chemical species that (due to their higher energetic state) deactivate through an oxidative process. The most reactive ROS are those belonging to the class of free radicals, such as hydroxyl $(\mathrm{HO} \bullet)$, alkoxide $(\mathrm{RO} \bullet)$, superoxide $\left(\mathrm{O}_{2}{ }^{\bullet-}\right)$, and peroxyl (ROO•). The species with paired electrons represent another ROS class; often, they are the product of the reactions of species from the first category, namely hydrogen peroxide $\left(\mathrm{H}_{2} \mathrm{O}_{2}\right)$, organic peroxide, ozone $\left(\mathrm{O}_{3}\right)$, or charged species, such as singlet oxygen $\left({ }^{1} \mathrm{O}_{2}\right)$ and excited carbonyl $\left(\mathrm{RCH}=\mathrm{O}^{*}\right)$ [11]. Oxygenfree radicals are produced as a result of exposure to polluted air, ultraviolet radiation, tobacco, alcohol, and drugs. The primary endogenous sources are cellular enzymes, myeloperoxidases (MPO), lipoxygenases, nicotinamide adenine dinucleotide phosphate (NADPH) oxidase (NOX) [12], and xanthine oxidase [13].

The oxidative interface is the boundary between ROS and the signaling molecules they activate; it describes how ROS directly activate oxidative stress-responsive pathways [14,15].

The oxidative stress could be defined as an imbalance between the production and ROS accumulation at the cell level and cells' capacity to inactivate them by using enzymatic reactions or other redox reactions $[10,16]$. Oxidative stress is the result of excessive production of ROS, which exceeds the capacity of the cellular antioxidant defense system to effectively remove them from the cells [14].

Antioxidants may be defined as reducing substances that oxidize, thus inhibiting another substrate's oxidation. Through a more complex mechanism, they have a kinetic effect of slowing down the oxidation reaction [17].

Superoxide anion is considered the primary free radical molecule formed in living organisms through chemical and biochemical reactions. Molecular oxygen $\left(\mathrm{O}_{2}\right)$ is converted into water at a mitochondrial level in the electron transport chain [18]. A small part of $\mathrm{O}_{2}$ is transformed into $\mathrm{O}_{2}{ }^{\bullet-}$, which further generates different reactive species, such as $\mathrm{HO} \bullet$ and $\mathrm{H}_{2} \mathrm{O}_{2}$; they produce other ROS by interacting with various organic molecules within the body. Frequently, superoxide radicals do not react directly with nucleic acids, carbohydrates, or polypeptides, determining the emergence of other reactive species, leading to oxidative processes $[18,19]$. In the human body, superoxide free radicals are 
inactivated under the actions of the superoxide dismutase enzyme (SOD), being converted into $\mathrm{H}_{2} \mathrm{O}_{2}$ within a two-phase chemical process [20,21].

Hydrogen peroxide is a regular metabolic product in the human body. When in higher quantities, it determines the production of $\mathrm{HO} \bullet$ through Fenton-type reactions.

It is impossible to determine $\mathrm{H}_{2} \mathrm{O}_{2}$ concentrations accurately because of the many factors that cause variations. Still, the values in plasmatic blood are around 1-5 $\mu \mathrm{M}$ [22]. Low concentrations of $\mathrm{H}_{2} \mathrm{O}_{2}$ are part of normal, adaptive processes as a response to stress. By contrast, high concentrations are included in oxidative stress, determining inflammations, senescence, and even cellular apoptosis. Moreover, $\mathrm{H}_{2} \mathrm{O}_{2}$ could be inactivated in the human body by endogenous antioxidants, such as catalase (CAT) and glutathione (GSH), in the presence of GSH peroxidase (GPx) [20].

Hydroxyl radical represents one of the most important free radicals belonging to ROS species. This radical is extremely reactive, and it is the main cause of lipid peroxidation. One of the main pathways to generate this radical within the human body is represented by Fenton reactions in the presence of metals [23].

ROS are involved in several physiological cellular functions, serving as important cellular messengers in normal signal transduction, gene regulation, and cell cycling [24]. ROS-induced cell signaling involves two general mechanisms: alterations in the intracellular redox state and oxidative modification of proteins [25]. Cells respond to ROS in different ways depending on the redox status. Under physiological conditions, increased production of ROS triggers cellular defense, and the mechanism against oxidative stress is activated by effectively removing ROS molecules from the cell [26].

High ROS concentrations may influence the induction or aggravation of several pathologies (Figure 1), such as hypertension [27], cardiovascular diseases, diabetes mellitus (DM) and its complications [28], metabolic syndrome [28-30], cancer [31], neurodegenerative diseases [32], or DNA mutations [33].

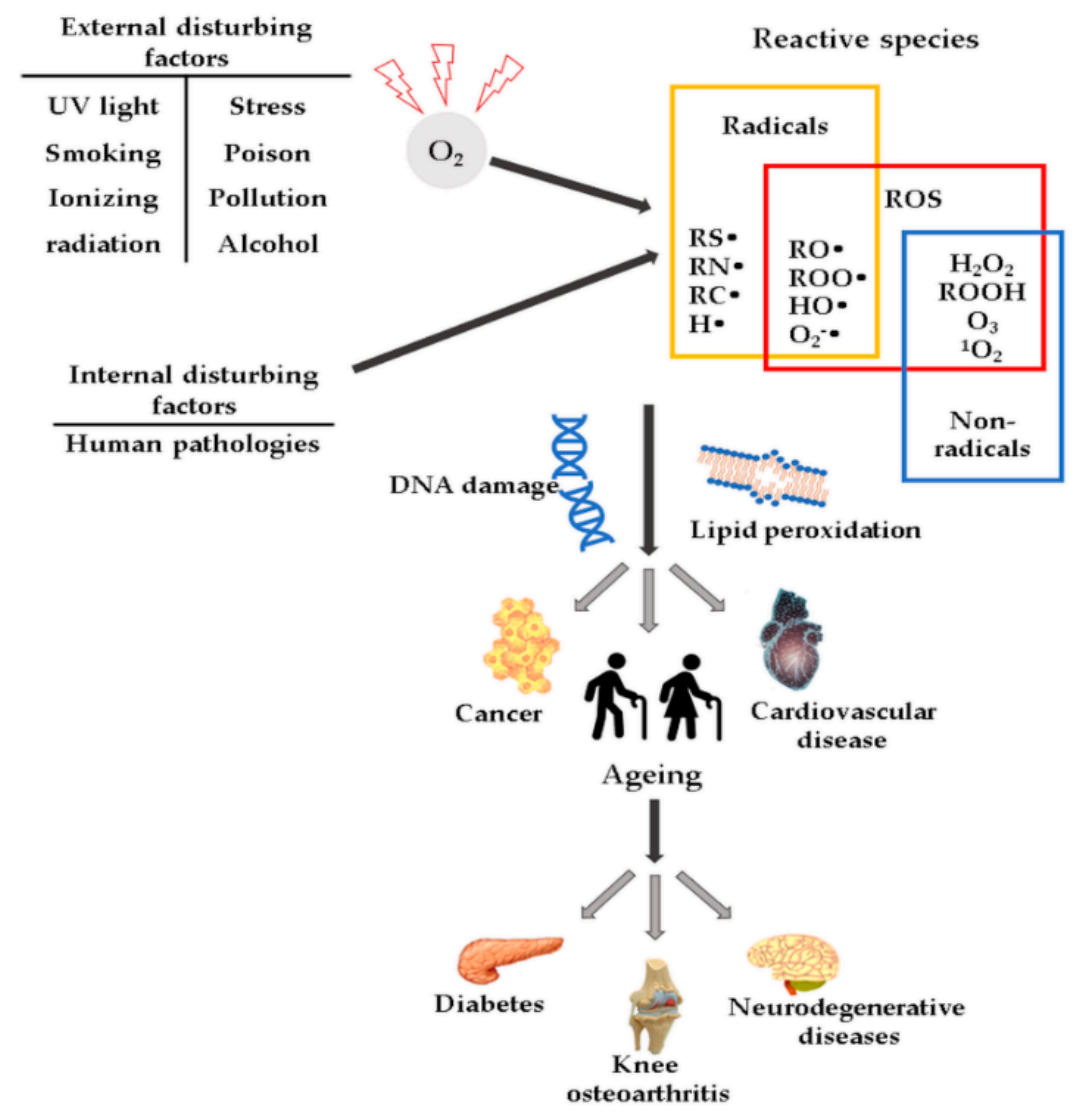

Figure 1. Schematic representation of ROS and their effects. 


\subsection{Antioxidants}

Antioxidants comprise several species that play a vital role in the suppression and prevention of free radicals, as well as in the neutralization of molecules with the potential of becoming free radicals. The human body controls the oxidative level through a series of enzymatic and nonenzymatic antioxidants [34].

\subsubsection{Enzymatic Antioxidants}

The enzymatic cellular antioxidant defense system includes various classes of enzymes, such as SOD, CAT, and GPx. Enzymes act specifically by eliminating ROS or synergically by catalyzing the regeneration of other antioxidants [35].

SOD is a class of enzymes comprising three isoenzymes with localization in extracellular, mitochondrial, or cytoplasmatic components. They have been found in reduced amounts in the case of KOA, especially the type 2 and 3 isoenzymes [35,36]. They have a role in converting $\mathrm{O}_{2}{ }^{--}$in $\mathrm{O}_{2}$ and $\mathrm{H}_{2} \mathrm{O}_{2}$, while higher serum levels of SOD are associated with lower general mortality rate among the feminine geriatric population [37].

CAT is an antioxidant enzyme with different localizations and a role in catalyzing $\mathrm{H}_{2} \mathrm{O}_{2}$ dismutation to water and oxygen. CAT plays an important role in $\mathrm{H}_{2} \mathrm{O}_{2}$ metabolism as a key regulator in maintaining cellular redox homeostasis [38]. Studies on lab animals have highlighted the antioxidant function of CAT, which increased the life span and reduced aging processes induced by oxidative stress [39]. Paradoxically, in the case of patients with $\mathrm{KOA}$, the CAT serum level is high. Upon correlating all evidence, it may be stated that this is due to the compensating protective role of CAT [40]. Collins et al. [39] confirmed these effects of CAT at the level of human chondrocytes and lab animal cartilages. Their studies presented a CAT-induced mitochondrial expression by mitigating ROS-induced oxidation and hyperoxidation of peroxiredoxins. The targeted expression of mitochondrial CAT has a role in decreasing ROS, as it helps cell survival and reduces the severity of arthritic symptoms. CAT-induced effects included reduced severity of degenerative alterations and increased survival rate of chondrocytes.

GPx is an enzyme with an important role in the reduction of $\mathrm{H}_{2} \mathrm{O}_{2}$ and lipid peroxides [41]. This enzyme has four isoforms with different locations. Thus, classic GPx is found in most cells of the body; the gastrointestinal isoenzyme (GI-GPx) is located in the gastrointestinal tract and forms a barrier against hydroperoxides derived from the diet. Plasma GPx is located in the plasma, and phospholipid hydroperoxide GPx is located in the mitochondria and is considered a universal antioxidant enzyme that acts on lipids and lipoproteins damaged by free radicals [42]. Prx enzymes have an antioxidant role at the intracellular level, also regulating redox signaling events. Prx enzymes are present in all types of tissues, including cartilage, where they act as redox signaling agents for target proteins containing thiol groups, with high activity against $\mathrm{H}_{2} \mathrm{O}_{2}$ [43]. Prx may disrupt cellular signaling in older adults because of the increased sensitivity to hyperoxidation, inhibiting their function by increasing intracellular ROS levels. In older adults, the Prx isoforms 1-3 have higher activity in chondrocytes under conditions of oxidative stress, compared to younger people. These imbalances suggest a phenotype typical of geriatric patients' tissues [39].

2.1.2. Nonenzymatic Antioxidants Comprise Compounds such as GSH, Carotenoids, Vitamin C, Vitamin E, or Coenzyme Q10

GSH- is an antioxidant of endogenous source; it is a tripeptide comprising amino acids such as glycine, L-glutamic acid, or L-cysteine [44]. It is found intracellularly in mitochondria and peroxisomes and has a role in preventing ROS-induced cellular degradation, which it can eliminate through enzymatic or nonenzymatic reactions. These reactions involve GPx, glutathione-S transferase (GST), glutathione reductase (GR), and modulations of the tertiary protein structure. In the cytoplasm, GSH is coupled to SOD and ensures the protection of subcellular structures against oxidative stress. The modifications of GSH con- 
centrations lead to cell senescence and apoptosis through alterations of their proliferation and the detoxifying and enzymatic transcription processes $[45,46]$.

Carotenoids are terpenoid pigments and are found in vegetables, fruits, shellfish, eggs, and meat. They are detected in the human body, and the most common isoforms are $\beta$-carotene, $\alpha$-carotene, lutein, or lycopene [47]. Carotenoids have antioxidant effects and inhibit the activation of nuclear factor kappa-light-chain enhancer of activated $B$ cells (NF-kB), interleukin (IL) -6, and tumor necrosis factor-alpha (TNF- $\alpha$ ). $\beta$-Carotene reacts with $\mathrm{ROO} \bullet, \mathrm{OH} \bullet$, and $\mathrm{O}_{2}{ }^{\bullet-}$ [48]. Vitamin $\mathrm{C}$ is an important nonenzymatic antioxidant that helps reduce free radical damage. Recent studies have shown that vitamin $C$ can have beneficial effects in patients with early KOA [49]. There are two isoforms of vitamin C transporters that are sodium dependent. At the level of articular cartilages, transporter 2 is mainly expressed, which is significantly altered in KOA grade III, compared to KOA grade I [50]. Vitamin C also acts as a biological modulator in immune cells; it is involved in the synthesis of collagen and catecholamines, and there is evidence that the administration of high doses of vitamin $C$ improves body function and the survival of critically ill patients [51]. Vitamin $\mathrm{E}$ is a powerful antioxidant that has a potential preventive or curative role in $\mathrm{KOA}$, due to its antioxidant and anti-inflammatory properties [52]. The antioxidant activity of vitamin $\mathrm{E}$ is due to the release of hydrogen from the hydroxyl group on the chromanol ring [53]. Vitamin $\mathrm{E}$ is a group of compounds, including tocopherols and tocotrienols, with alpha-, beta-, gamma-, and delta isoforms [54], of which alpha-tocopherol is the most important one [55]. Alpha-tocopherol can have both antioxidant and pro-oxidant effects when present in high doses by acting on vitamin $\mathrm{K}$ at the bone level and could block other types of vitamin E isomers [55]. Previous studies have demonstrated that the antioxidant activity of tocotrienol is superior to that of alpha-tocopherol [56,57]. Coenzyme Q10 is a coenzyme for mitochondrial enzymes involved in the electron transport chain and has a role in adenosine triphosphate (ATP) synthesis. It has an antioxidant effect by inhibiting the peroxidation of plasma lipoproteins and lipids of cell membranes, but its anti-inflammatory effects have also been highlighted. The antioxidative and anti-inflammatory effects have been demonstrated in animal studies when it was observed that the oxidative stress was reduced and the histological score of the cartilages affected by KOA was improved $[58,59]$.

\section{ROS Implication in KOA Pathogenesis}

ROS are considered key etiological factors involved in the pathogenesis of many age-related diseases [34]. A typical geriatric patient is characterized by a fragile state with a low functional reserve; thus, such patients are more prone to oxidative stress, stress factors, and inflammation [60]. The impact of aging on the cartilage structure is also highlighted by the macroscopic appearance of the tissue among subjects of various ages. Although still intact and smooth in elderly patients, the cartilage is thin and brownish [61]. The accumulation of degradation products may cause this appearance and the alterations recorded in chondrocytes functions [62]. The exogenous and endogenous factors to which the human body is exposed over time act on all these processes, leading to destructive effects that may or may not be remedied [63].

\subsection{ROS, Aging, and Inflammation in KOA Pathogenesis}

ROS could affect the musculoskeletal system, including multiple cellular structures at the bone level [64].

The pathophysiology of KOA involves inflammatory and degenerative processes related to oxidative stress [65]. Low-grade systemic inflammation can be caused by aging [66] and can affect the knee joint by supporting local inflammation [67]. Inflammation and oxidative stress are interdependent and activate the signal transduction pathways in cartilage, producing a phenotypic change characterized by the inability of KOA chondrocytes to maintain tissue homeostasis $[68,69]$. Inflammatory changes decrease the level of antioxidant enzymes in biological fluids and cartilage and increase the level of oxidative agents, affecting proteins with a role in structural strength [24]. Figure 2 suggests the 
interdependence relationship between oxidative stress and inflammation, showing the cycling sequence, in which the oxidative stress and synovial inflammation are intensifying each other.

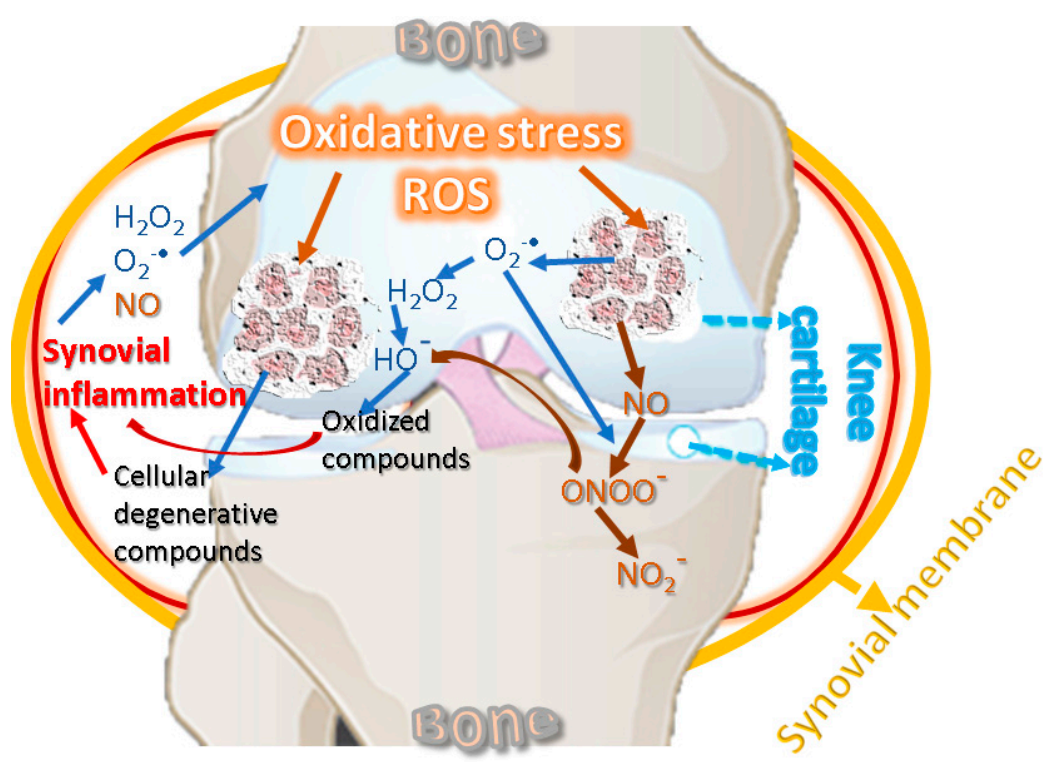

Figure 2. Oxidative stress and inflammation reciprocal cause-and-effect cycle.

ROS are also produced by the NOX group [24], which comprises several forms, such as NOX1, NOX2, NOX3, NOX4, and NOX 5 [70]. The NOX-mediated ROS signaling underscores an isoform-specific to this oxidase, namely NOX4, targeting chondrocytes with a role in the standard final pathway [71]. ROS are key factors in the chondrocytes apoptosis because these could induce the appearance of the others. Under normal conditions, ROS products are used in joint chondrocytes to maintain cartilage homeostasis, actively participating in intracellular signaling. For example, in human chondrocytes, NOX produces $\mathrm{O}_{2} \bullet-$, which further generates $\mathrm{H}_{2} \mathrm{O}_{2}$ and $\mathrm{HO} \bullet$ radicals $[36,72,73]$. Under pathological conditions, chondrocytes produce an important amount of reactive species [74], and NOX induces ROS synthesis in the synovial fluid, leading to oxidative stress, thus contributing to cartilage degradation [75]. The main ROS affecting cartilage detected in chondrocytes are $\mathrm{H}_{2} \mathrm{O}_{2}$ and peroxynitrite. In chondrocytes, ferrous ion $\left(\mathrm{Fe}^{2+}\right)$ and $\mathrm{H}_{2} \mathrm{O}_{2}$ produce $\mathrm{HO} \bullet$, which reacts with the unsaturated fatty acids of membrane lipids, thus forming lipid radicals RO• and ROO•. ROS are neutralized by elimination systems, namely, SOD, CAT, GPx, GR, and GSH, but limited antioxidant capacity has been reported in KOA human cartilage and experimental animal models. Therefore, oxidative stress leads to membrane and nucleic acid damage, as well as to the breakdown of extracellular components, including proteoglycans, collagens, and cartilage destruction $[20,23,45]$. Similarly, in vitro studies performed on bovine chondrocytes suggested that $\mathrm{O}_{2}{ }^{--}$is involved in load-induced KOA development [76]. Chondrocytes are cells of cartilages, avascular, and innervation-free tissues that allow oxygen to diffuse into superficial areas producing ROS [77]. In pathologies such as KOA that combine mechanical and inflammatory stress, as well as variations in oxygen pressure, chondrocytes produce much higher levels of ROS through NADPH [78]. ROS shows inhibitory effects in cartilage synthesis by inhibiting the synthesis of proteoglycans by $\mathrm{NO}$ in the superficial and deep layers of cartilage [79], and $\mathrm{H}_{2} \mathrm{O}_{2}$ inhibits their synthesis inside chondrocytes by forming ATP and suppressing mitochondrial oxidative phosphorylation [80].

Excess $\mathrm{O}_{2}{ }^{--}$in mechanical overloading conditions was confirmed indirectly by biochemical analyses (flow cytometry) of cartilage taken from patients with KOA. Thus, the correlation between decreased SOD concentration and cartilage degeneration in the progression of KOA was highlighted [81]. These observations correlate well with the 
general idea that antioxidant enzymes, such as SOD, CAT, and GPx, have low levels in patients with KOA, suggesting the critical role that ROS and oxidative stress play in this pathology [82-84]. Therefore, reduced quantities of antioxidant enzymes determine high oxidative and metabolic stress for cartilages, at a level where, besides all the molecular and functional alterations, changes are also noted in the ratio between collagen and proteoglycans, thus favoring the onset of degenerative changes $[85,86]$. In addition, with aging, chondrocytes become more sensitive to the action of ROS, which is associated with an increase in inflammation mediators at serum level, impacting the extracellular matrix, producing chondrocytes senescence and apoptosis [85], and causing joint cartilage degeneration (Figure 3), subchondral sclerosis, and damage of meniscal and ligament structures [87]. The presence of lipid peroxidation products in the case of KOA was correlated with the action of ROS. Thus, the level of oxidized low-density lipoprotein (ox-LDL), nitrated derivatives, nitrotyrosine, or nitrite in the cartilage and the biological fluids evidence the ROS implication $[88,89]$. The KOA pathogenesis depends extensively on the infrapatellar pad and menisci. It has been reported that in the case of KOA, the meniscal cells produce increased levels of inducible nitric oxide synthases (iNOS) and NO [90], while the KOA progression is favored by the infrapatellar fat pad known as a source of inflammatory mediators [91].

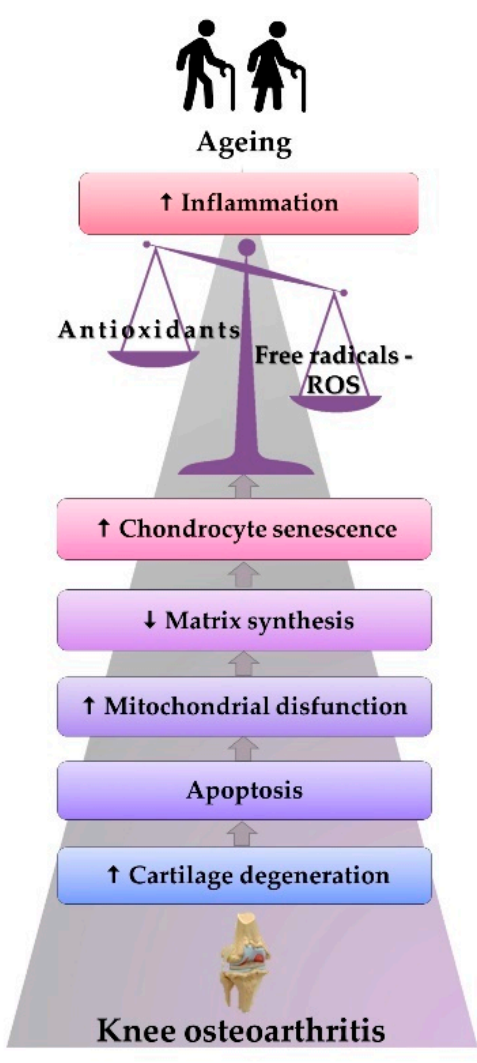

Figure 3. The physiopathological mechanism of ROS-induced KOA.

Figure 3 features KOA stages among older adults: aging is correlated with the effects generated by the increase in the inflammatory status and oxidative stress. Such stress causes the onset of mitochondrial dysfunctions and a decrease in matrix synthesis. All the alterations accelerate chondrocytes' senescence, leading to apoptosis, cartilage degeneration, and the beginning of KOA.

The susceptibility to changes generated by ROS is highest at the superficial layer of the knee cartilage, which has direct contact with the synovial fluid containing free radicals and inflammatory cells. The long-term action of ROS, as well as the intense activity of inflammatory and mechanical factors, modifies the structure of collagen fibers and causes 
the thinning of the proteoglycans layer. Moreover, functional alterations affect the deeper cartilage areas [86]. As a result, the main symptoms of KOA consist in pain and functional impotence [92], in association with radiological changes [93]. It is worth mentioning here that ROS have important implications in the induction of a senescence secretory phenotype, thus resulting in supporting the inflammatory status by increasing the production of IL-1 and IL-6, or matrix metalloproteinases (MMPs) [85].

Oxidative stress also induces the activation of the NF- $\mathrm{kB}$ pathway and MMPs overproduction, thus triggering DNA damage and cell senescence $[68,69,94]$. Several studies demonstrated the pivotal role of NF- $\mathrm{KB}$ in KOA pathogenesis. The family of transcription factors NF- $\mathrm{kB}$ have a central role not only in the proinflammatory stress-related responses of chondrocytes but also in the control of their differentiation program. NF- $\mathrm{kB}$ is activated by the signalosome complex, a molecular switch controlled by two pivotal serine-threonine kinases that can remove NF- $\mathrm{KB}$ inhibitors, which block NF- $\mathrm{KB}$ transcriptional activities: inhibitors of nuclear factor kappa-B kinase (IKK) $\beta$ and IKK $\alpha[66,69]$. Abnormal NF- $k B$ activation produced the loss of the growth-arrested state of articular chondrocytes, being accompanied by the production of procatabolic mediators. Among these mediators are included the aggrecanases and MMPs, which induce cartilage degradation, as well as the proinflammatory cytokines. Further, continued NF- $\mathrm{kB}$ activation results in the overexpression and activation of other regulatory transcription factors, perpetuating KOA disease via modulation of inflammatory and catabolic mediators, and linking hypertrophic-like conversion with inflammation. Together, these signaling networks collaborate to activate MMP13 expression and activity and facilitate the progression of normal articular chondrocytes to a hypertrophic-like KOA phenotype, thereby also contributing to KOA onset and/or progression $[68,69]$.

\subsection{ROS, Damage of Genomic and Mitochondrial DNA, and Cell Senescence}

Oxidative stress also affects DNA: it accelerates senescence and stimulates the activation of molecule cascades, generating the onset of cellular apoptosis. Mitochondrial DNA (mtDNA) haplogroups, which mediate energy production, cell growth, and cell signaling for molecular pathways [95], have also been associated with specific population groups with KOA radiological changes, for instance haplogroup $\mathrm{H}$, or lower level of free radicals and proapoptotic gene expression at the mitochondrial level and thus a lower grade of cellular apoptosis, as in the case of haplogroup J [96]. These different ways of influencing certain pathologies are explained by the fact that haplogroups have different rates of ROS and energy production. For example, in haplogroup $\mathrm{H}$, high amounts of energy and ATP are produced, while an excess release of ROS and cellular degenerescence occur [95].

In $\mathrm{KOA}$, catabolic processes are accentuated by the combined action of oxidative stress and proinflammatory state, and mechanical factors, entailing high ROS levels and low amounts of antioxidants [97,98]. The low concentrations of antioxidants amplify ROS signaling and favor mitochondrial dysfunction in chondrocytes [99]. These alterations at the mitochondrial level occurred because of the ATP-altered synthesis and decreased electrons within the mitochondrial electron transport chain [100]. Increased ROS concentration and aging are also determined by an interruption of cell signaling at the mitochondrial level, accompanied by the production of specific cell dysfunctions and sometimes tissue dysfunctions [101]. When homeostasis is present at the level of bone tissues, the differentiation of osteoblasts and bone formation is ensured by mitochondria. The increase in ATP production and mitochondrial stress induced the activity of SOD isoform 2. This antioxidant enzyme has a role in reducing oxidative stress, improving osteoblast differentiation, bone remodeling, and mitochondrial stress regulation [102]. Such a statement is based on the hypothesis that there is a direct effect of inflammatory molecules on DNA mutations [103]. Persistent mtDNA damage is recognized as a hallmark of chronic degenerative diseases [68]. The mtDNA damage is considered responsible for the senescence of OA chondrocytes, which may be caused by an increase in mitochondrial ROS production and shortening of telomeres, which is dependent on stress factors [104]. Moreover, ROS induces 
matrix loss, premature senescence, mitochondrial dysfunction, apoptosis of chondrocytes, mesenchymal stem cells [105], and subchondral bone mass loss [106]. The inhibitory effect of oxidative stress in bone remodeling was revealed by the low serum level of certain antioxidants and the increase in the concentration of lipid peroxides; these specific serum levels highlighted a disturbance of the redox balance, with harmful effects of ROS on the DNA [107]. The resulted dysfunctions and the generation of cytotoxicity lead to lower levels of antioxidant enzymes in biological fluids and cartilages, as well as an increase in oxidative markers affecting the proteins that ensure structural resistance [24]. Therefore, similarly to other pathologies [108], in KOA, the correlation with molecular biomarkers is important [24].

\section{Markers of Oxidative Stress in Older Adults with KOA}

Biomarkers must meet certain criteria to be used in medical practice. They must allow easy sampling, and they should be reproducible. At the same time, it should have diagnostic and prognostic specificity and be able to correlate with the severity of the pathology in order to evaluate the effectiveness of the treatment [109]. Although multiple determinations of oxidative stress markers and antioxidant status are performed, dosing on large groups of patients is required for clinical and diagnostic validation. Because oxidative stress characterizes several pathologies [110-112], it is vital to perform a targeted selection of biomarkers in accordance with each disease $[109,113]$. The biomarkers for oxidative stress or the antioxidant markers can be measured in blood, urine, or saliva samples [114], as well as in the expired air by different analytical methods [115].

Lipid peroxidation involves changes in the composition and structure of cells, with adverse effects on their function [116]. The lipid membrane is affected by oxidative stress related to aging. There are known two types of lipid peroxides: endoperoxides and hydroperoxides. They generate aldehyde products, such as malondialdehyde (MDA). Such products have destructive effects on the extracellular matrix, cellular components, and implicitly on the proteins and DNA [117], also producing other metabolites, such as 4-hydroxynonenal (4-HNE), F2-isoprostanes (F2-IsoPs), acrolein, hexanoyl-lysine, or ox-LDL [118]. After local injection of 4-HNE to animals, macroscopic and microscopic changes in articular cartilage and increased concentrations of inflammatory markers were observed [119]. The determination of lipid peroxidation markers can be performed using chromatography, mass spectrometry (MS), or spectrophotometric absorption analysis. These are sensitive procedures that ensure the monitoring of multiple reactions, maintaining the stability of the analyte and of certain isotope species [120].

MDA is a toxic aldehyde and is used as a biomarker of lipid peroxidation [121]. There are several extremely precise methods of analysis, such as reverse-phase high-performance liquid chromatography and modified 2-thiobarbituric acid spectrophotometric method [120,122]. The dosage can be performed in human plasma by 2,4-dinitrophenylhydrazine derivatization, and the results can be used to assess the carbonylation of proteins, or the oxidation of lipids and proteins [123]. MDA presents high values in KOA, having effects on the degradation and oxidation of collagen in cartilage. Thus, Gavriilidis et al. [99] observed a significant $6.5 \%$ increase in MDA values in patients with $\mathrm{KOA}$, compared to a control group. Elevated MDA levels have also been associated with other conditions, such as lung diseases [124]. Comparative analysis of certain free radical types present in the plasma and the synovial fluid from KOA patients and a control group has shown significantly higher plasma values for the test group. Among patients with KOA, MDA was recorded in substantially higher amounts in the plasma and synovial fluid. In addition, severe changes in grades III and IV of KOA, according to the radiological Kellgren-Lawrence classification system (KL), were correlated with high serum levels of free radicals and MDA [125]. According to the researchers, relatively low MDA levels in certain groups of the geriatric population could indicate the presence of a genetic component with a protective effect against oxidative stress [126]. Regarding the administration of certain exogenous antioxidants, the concentration of MDA can be reduced by curcuma [127], turmeric [128], and ginger extracts [129]. 
MPO is a proinflammatory hem peroxidase expressed in lymphocytes, leukocytes, or neutrophils, and is released following cell degranulation. It also generates ROS during phagocytosis in response to microbial attack. However, in uncontrolled degranulation processes, it can cause tissue damage and aggravate inflammation even in the absence of infectious processes [130]. It can be used as an indirect biomarker measurement or for assessing MPO-specific biomarkers, such as chlorotyrosine, glutathione sulfonamide, or chlorinated lipids [131]. Geriatric pathologies that can be associated with high concentrations of MPO comprise KOA [132], DM, liver [130], or cardiovascular diseases [133].

Isoprostanes (IsoPs) are generated by the peroxidation of polyunsaturated fatty acids. The species F2-IsoPs are the most common, derived from arachidonic acid [134], and can be used as a mediator of oxidative stress or a nonenzymatic biomarker of endogenous lipid peroxidation $[135,136]$. Elevated concentrations of IsoPs were detected in serum, synovial fluid, and synovial membrane biopsy in patients with KOA or meniscal and cruciate ligament lesions [137]. The determinations could be performed from plasma, saliva [138], cerebrospinal fluid samples [136], or various tissue types, by gas chromatography-mass spectrometry (GC-MS) methods [138]. Decreased F2-IsoPs levels are associated with vitamin C administration [139] and with the consumption of antioxidant-rich fruits [140].

Protein carbonyl can be used as a marker of protein oxidation, the carbonylation process being irreversible and generating changes in DNA and enzymatic activities of the transcription factors [141]. The serum concentration of carbonylated proteins correlates negatively with albumin levels, an extracellular molecule known as positive acute-phase protein. Such correlation reflects the fact that a low level of serum albumin signals the presence of inflammation and oxidative stress [142]. Elevated carbonyl protein levels have been detected in multiple pathologies, such as DM [143], rheumatoid arthritis [144], chronic renal failure, or sepsis [145].

ROS-induced gene changes are premutagenic lesions, and guanine has the most remarkable predisposition to genome oxidation. Oxidation of the guanine base results in 7,8-dihydro-8-oxoguanine, which is considered a biomarker of oxidative DNA damage [146]. DNA mutations, with their effects on proteins and gene expression, have been considered one of the main causes of aging. These changes are associated with decreased B cell function [147], as seen in the cartilage affected by OA [148], at the neuronal level in the elderly [149], or in skeletal muscle, where approximately 13 somatic mutations per genome were recorded annually [150]. However, there is no direct evidence for attributing the aging process to DNA mutations [151].

Excessive ROS causes the oxidation of DNA, and the oxidized nucleosides are excreted in urine, so that the overall rate of DNA oxidation can be obtained noninvasively [152]. Measurements can also be made from peripheral blood, but this type of sampling has some drawbacks, for example, a longer working time, or possible damage to samples when they are improperly stored. New technologies have allowed the development of investigation methods that enable capillary blood dosing [153].

In medical practice, the analysis of total antioxidative capacity (TAC) or measuring its enzymatic or nonenzymatic markers is commonly used [154]. The assessment of the redox status can also include antioxidant markers that may be enzymatic, such as SOD, CAT, GPx, and TAC [155], or nonenzymatic, such as coenzyme Q10, GSH, retinoids, transferrin, ceruloplasmin, carotenoids, vitamin E, vitamin C, albumin, and uric acid [156].

TAC is a biomarker used to assess the body's antioxidant potential [157]. However, since the enzymatic activities are excluded and thus the determination is only partial, the term nonenzymatic antioxidant capacity (NEAC) could be more appropriate [158]. Its determination is of real interest in medical practice; hence, several investigation methods have been developed [159]. The analysis can be performed from different types of biological fluids, such as peripheral blood, saliva, or urine. Because existing pathologies may influence the respiratory or urinary tract values, the analysis of urine and saliva should consider the influencing factors [157]. An optimal level of NEAC has been correlated with 
decreased risk of coronary events $[160,161]$ and reduced degenerative changes in knee cartilage [162].

SOD can be used as a marker of antioxidant enzyme capacity. According to Koike et al. [163], this enzyme correlated with low synovial fluid levels in patients with KOA. These observations could indicate that, as SOD activity is not influenced by age, its corrections at the joint level could slow OA progression. During their investigations, FernandezMoreno et al. [154] found elevated SOD2 values in KL IV KOA cases. The researchers explained the findings through a compensatory mechanism of the body to cope with increased ROS concentrations. These results highlight the importance of correlating the ROS concentrations, determined using oxidative stress markers, with TAC, the clinical applicability of this assessment being of real interest for KOA in geriatric patients.

CAT is an enzyme with an important antioxidant role, whose benefits in chondrocytes have been proven by lowering ROS levels, reducing TNF- $\alpha$-induced apoptosis, and physiological remodeling of cartilage [164].

GPx is an enzyme that can reduce large amounts of hydroperoxide radical. GPx serum levels are measured to assess the body's oxidative state [165]. KOA is correlated with low levels of GPx, which could be a side effect induced by high doses of nonsteroidal anti-inflammatory drugs [166]. In addition, the GSH/glutathione disulfide (GSSG) ratio allows the oxidative stress evaluation [167].

Research in mice to evaluate cartilage changes in OA using equilibrium partitioning of an ionic contrast agent via microfocal computed tomography, in correlation with ROS quantification and characterization by in vivo fluorescence imaging, revealed the presence of higher ROS amounts in the first day after experimentally inducing KOA [168]. The low level of antioxidant enzymes, especially SOD and GPx, was correlated by Paździor et al. [169] with KOA imaging changes, which were observed using conventional radiology, ultrasounds, or computed tomography, when investigating older female patients.

S-glutathionylated proteins are oxidized proteins that characterize chronic inflammation and induce metabolic stress changes in monocytes and macrophages. They are also associated with aging, DM, cancer, or heart diseases [170].

Nonenzymatic markers have also been studied in the context of KOA: vitamin E, vitamin C, and coenzyme Q10. For instance, vitamin E is a powerful antioxidant of plant origin [55]. Lower concentrations of vitamin $\mathrm{E}$ in serum or synovial fluid were detected in patients with KOA, compared to healthy persons. Vitamin $\mathrm{E}$ is thought to relieve oxidative stress and joint inflammation by slowing KOA progression [52]. In a prospective longitudinal observational cohort study, the increased level of serum vitamin C was associated with better functional capacity and less pain in the knee joint [171]. Vitamins E and C, MDA, and 8-hydroxy-2-deoxyguanosine-marker of oxidized DNA can be used as biomarkers in other pathologies, other than $\mathrm{KOA}$, when low concentrations of vitamin $\mathrm{E}$ and $\mathrm{C}$ and high levels of MDA and 8-hydroxy-2-deoxyguanosine were detected [114]. Objectifying the effects of vitamin $\mathrm{E}$ in KOA, through tests performed on lab animals, consisted in decreasing TNF- $\alpha$ and IL-6 [172]. In addition, other inflammatory markers within KOA are represented by TNF- $\alpha$ and IL-1 $\beta$, IL-6, IL-15, IL-17, and IL-18, with a consecutively increasing effect of MMPs $[173,174]$. An inflammatory process lowers the concentration of antioxidants and increases the oxidative stress. At the same time, such alterations result in a decrease in type II collagen synthesis and in the acceleration of chondrocytes senescence. In these processes, specific degradation products induce changes in the cartilage properties, with excess production of MMPs and cytokines, thus leading to degenerative changes $[173,175]$.

Coenzyme Q10 decreased pain intensity and cartilage degeneration and reduced MMPs, IL-6, IL-15, and nitrotyrosine levels [59]. 


\section{The Effects of Antioxidants in KOA}

\subsection{Antioxidants and Their Metabolism}

Considering that ROS overproduction leads to the emergence of oxidative stress, which has a role in the mechanisms of aging and the pathogenesis of many disorders among the geriatric population, restoring the redox balance is of essential importance. A reduction in the concentration of oxidant species may be achieved by using antioxidants. The human body controls the oxidative level through a series of endogenous antioxidants, enzymatical or nonenzymatical such as vitamins. Enzymes act specifically by eliminating ROS or synergically by catalyzing the regeneration of other antioxidants (for example, GR that regenerates GSH). In nature, there is a significant number of plant origin antioxidants, such as phenolic acids, flavonoids, carotenoids, and vitamins, which could be used to restore the oxidant-antioxidant balance [176]. In addition to natural antioxidants, synthetic ones have played an increasingly significant role in modern therapy. In this context, nanotechnologies have considerable implications in all areas of medicine, thus defining a new domain: nanomedicine. In this context, experts have synthesized magnetic vectors for the targeted delivery of antioxidants [177,178].

Based on the studies that revealed the helpful action of the antioxidants from the diet in relieving KOA symptoms, antioxidant-based therapies to restore the oxidative balance have been developed. Although there are publications that guarantee the beneficial effect of an adjuvant treatment with natural antioxidants, for their correct evaluation, it must be considered that the in vivo properties of exogenous antioxidants depend crucially on their stability. The key factor is the path of metabolic transformations, considering that the liver and the gastrointestinal tract generate metabolites with properties similar to, or different from, those of the original antioxidants. Therefore, it is vital to know the metabolic conversion of natural antioxidants to establish the opportunity of their application in adjuvant therapy. It should be noted that some natural antioxidants have reduced solubility in water and low bioavailability. The difficulty of passing through lipid membranes reduces the effectiveness of water-soluble antioxidants. All these characteristics condition the administration of antioxidants in high doses for satisfactory efficiency. Some authors noted that the treatment for $\mathrm{KOA}$ is recommended to be delivered directly into the synovial capsule, the location of the affected tissues being an advantage in this regard $[179,180]$, although this practice sometimes showed a weak penetration of the cartilage [181]. Lately, nanotechnology has offered solutions to overcome some of the shortcomings discussed above. In recent years, functional metal oxide nanosystems have been developed to transport agents of natural [182] or synthetic antioxidants [178]. The most efficient nanosystems were made up of soft nanoparticles, such as polymeric micelles [183], nanoemulsions [184], and lipid vesicles [185].

Although studies show the molecular action mechanisms at the cellular level of exogenous antioxidants and their interactive or synergistic behavior toward endogenous antioxidants, we observed that all the discussed mechanisms, from the introduction of antioxidants into the body to the delivery to the targeted tissue, are still under debate, lacking concrete data. In this context, it is insufficiently documented how the antioxidant acts at the molecular level in the knee area when treatment of KOA with exogenous antioxidants is proposed. Consequently, it is complicated, or almost impossible, to establish a metabolic pathway from ingestion of exogenous antioxidants to the site of action represented by the knee. Given the existence of many publications in the field, we selected some antioxidants with beneficial effects in relieving OA, in order to analyze how they are metabolized in the human body and which are the key factors conditioning the pathology improvement [179].

Flavonoids found in vegetables in a glycosylated form are commonly listed as antioxidants in our diet. In an early metabolic stage, the flavonoids are deglycosylated [186,187], and then they are O-methylated at the catechol moiety in the liver and small intestine [187-189].

The changes of the antioxidant molecules can be even more drastic because, inside the colon, flavonoids can undergo destructive processes at the molecular level, transforming into smaller molecules with phenolic structure [188,190]. One of the most important 
flavonoid representatives, quercetin, causes the appearance of metabolic derivatives with antioxidant properties [191-193]. Morand et al. [194] showed that in plasma, most quercetin metabolites consist of quercetin-4'-O- sulphate, or 3'-O-methyl quercetin, and other derivatives with antioxidant properties [195]. The authors pointed out that their beneficial effects depend strongly on the regular consumption of plants containing polyphenols, as their effects decrease drastically in the first $20 \mathrm{~h}$ after ingestion $[194,196]$. The effects of quercetin on KOA changes were evaluated in animal studies and evidenced an increase in SOD concentration and tissue MMPs inhibitor of cartilage extracellular matrix degradation [197].

Resveratrol is a polyphenolic antioxidant found in peanuts, grapes, and teas. Resveratrol undergoes radical transformations in the human body in the gastrointestinal tract, leading to different products distributed in various organs. Springer and Moco [198] eloquently outline the complexity of resveratrol transformations. The compound undergoes sulfation and glucuronidation in the small intestine, while in the large intestine, it is metabolized by microorganisms resulting in dihydroresveratrol, lunularin, and 3,4'-dihydroxy-transstilbene. Resveratrol can also be metabolized in the liver and kidneys. Furthermore, the authors [198] have made an extensive assay, in which they put forward a list of resveratrol metabolites correlated with their presence in organs: trans-resveratrol4'-O-glucuronides, trans-resveratrol-3-O-sulfate, dihydroresveratrol-glucuronide-sulfate, dihydroresveratrol-glucuronide-sulfate, and many others.

Chlorogenic acid is an antioxidant found in larger amounts in coffee beans. Studies have shown that chlorogenic acid is stable in gastric fluids [199]. Although the metabolism of chlorogenic acid is extremely complex, the number of resulting derivatives being relatively high, its metabolic processes have been efficiently reviewed [200]. In this context, Farah and Duarte [201] proposed a concise scheme for the metabolic pathway of chlorogenic acids, highlighting the intermediates and final products with antioxidant properties, such as caffeic acid, vanilla, syringic acid, protocatechuic acid, and others, to illustrate the complex reaction pathways.

Oleuropein is a polyphenol found in olives and, to a greater extent, in olive leaves. Bock and coworkers quantified the bioavailability and oleuropein and hydroxytyrosol metabolism in human volunteers who were given olive leaf extract in various formulations [202]. MS analysis of urine and plasma showed different distributions in the two fluids depending on the oleuropein and hydroxytyrosol conjugates formulation (sulfated and glucuronidated) as part of the oleuropein transformation. The metabolite glucuronidated hydroxytyrosol is a free radical scavenger five times more efficient than hydroxytyrosol [203]. Oleuropein has shown high stability during digestion, while its glycosidated form reaches the colon and is transformed into a wide range of products due to microbial fermentation [204,205], mostly into its deglycosylated form and hydroxytyrosol [206]. Some urinary metabolic derivatives of oleuropein have been highlighted, such as oleuropein aglycone, hydroxytyrosol, homovanillyl alcohol, and an isomer of homovanillyl alcohol [207]. Although there are many published data, oleuropein is insufficiently studied in terms of metabolites found in various organs of the human body.

Catechins are polyphenols found in significant amounts in green tea (Camellia sinensis), which have antioxidant properties. Catechins are stable enough to be excreted in feces, but most undergo conjugation reactions (glucuronide and sulfate formation) [208]. Some metabolic studies have shown that epigallocatechin-3-gallate can accumulate in the blood in a concentration high enough to exert antioxidant activity [209,210]. The metabolic products of catechins include glucuronides, sulfate conjugates, and methylated metabolites, most of which are metabolized in the liver and small intestine. Catechins undergo extensive transformations in the colon due to the action of microbes, leading to simple polyphenols [211].

Curcumin has been used in the study and treatment of clinical diseases due to its pharmacological properties [212]. Although oral curcumin supplementation has shown therapeutic efficacy in many clinical studies, its properties are counteracted by reduced bioavailability, low absorption, rapid metabolism, and elimination [213]. These shortcom- 
ings can be avoided using various drug formulations [179,213]. The curcumin metabolism occurs through oxidation, cleavage, conjugation, and reduction. It has been proved that curcumin is rapidly metabolized in the cell culture state and in vivo, mainly by reduction and conjugation [214]. Curcumin is conjugated to produce glucuronides and curcumin sulfates or is reduced to hexahydrocurcumin in the liver or intestines. Intraperitoneal or systemic administration reduces curcumin to tetrahydrocurcumin, hexahydrocurcumin, and octahydrocurcumin. Curcumin has limited stability and can degrade under physiological conditions. The degradation products were identified as trans-6-(40-hydroxy-30methoxyphenyl)-2,4-dioxo-5-hexenal, ferulic acid, feruloyl methane, and vanillin. Some of the degrading curcumin products, such as ferulic acid or vanillin, may be associated with antioxidant activity [215].

In Table 1, the effects of the mentioned antioxidants in KOA context and the characteristics of the studies performed to determine their potentially chondroprotective and anti-inflammatory action are summarized.

Table 1. Antioxidants and Their Effect on KOA.

\begin{tabular}{|c|c|c|c|c|c|}
\hline Antioxidant & Type of Study & Dosage/Time & $\begin{array}{c}\text { Studied } \\
\text { Samples/Analytes }\end{array}$ & Effect & Ref. \\
\hline Quercitin & $\begin{array}{l}\text { Animal model } \\
\text { (rabbit) } \\
48 \text { subjects/ } \\
16 \text { controls }\end{array}$ & $\begin{array}{l}25 \mathrm{mg} / \mathrm{kg} \\
4 \text { weeks }\end{array}$ & $\begin{array}{l}\text { serum, synovial } \\
\text { fluid, and synovial } \\
\text { tissue } \\
\text { SOD } \\
\text { TIMP-1 } \\
\text { MMP-13 }\end{array}$ & $\begin{array}{l}\nearrow \text { SOD and TIMP-1 } \\
\searrow \text { MMP-13 } \\
\nearrow \text { KOA degeneration } \\
\searrow \text { cartilage degradation }\end{array}$ & [197] \\
\hline $\begin{array}{l}\text { Olive Leaf Extract } \\
\text { standardized for } \\
\text { oleuropein content }\end{array}$ & $\begin{array}{l}\text { In vivo, } \\
\text { Randomized, } \\
\text { double-blind, } \\
\text { placebo-controlled, } \\
\text { multi-centric trial } \\
124 \text { subjects/ } \\
\text { mild disease }\end{array}$ & $\begin{array}{l}50 \mathrm{mg} \\
6 \text { months }\end{array}$ & $\begin{array}{l}\text { serum } \\
\text { Coll2-1NO2 } \\
\text { MPO } \\
\text { Osteocalcin }\end{array}$ & $\begin{array}{l}\text {-no significant changes of } \\
\text { inflammatory and cartilage } \\
\text { remodeling biomarkers for } \\
\text { low to moderate KOA } \\
\text {-no significant changes of } \\
\text { inflammatory and cartilage } \\
\text { remodeling biomarker }\end{array}$ & [207] \\
\hline Oleuropein & $\begin{array}{l}\text { In vitro } \\
\text { Human } \\
\text { condrocytes }\end{array}$ & $10,50,100 \mu \mathrm{M} / 2 \mathrm{~h}$ & $\begin{array}{l}\text { chondrocytes } \\
\text { culture } \\
\text { COX-2 } \\
\text { iNOS } \\
\text { NO- } \\
\text { PGE }_{2} \\
\text { MMP-1, MMP-13 }\end{array}$ & $\begin{array}{l}\searrow \text { NO production } \\
\searrow \text { PGE } 2 \text { production } \\
\searrow \text { COX-2 \iNOS } \\
\searrow M M P-1 \\
\searrow \text { MMP-13 } \\
\searrow \text { ADAMTS-5 Suppresses } \\
\text { NF- } \mathrm{B}, \text { MAPK activation }\end{array}$ & [216] \\
\hline Curcumin & $\begin{array}{l}\text { Animal model } \\
\text { (mouse) } \\
\text { synovial fluid of } \\
\text { knee joints } \\
30 \text { subjects / } \\
15 \text { controls }\end{array}$ & $\begin{array}{l}40 \mu \mathrm{mol} / \mathrm{L} / \\
72 \mathrm{~h}\end{array}$ & $\begin{array}{l}\text { synovial fluid } \\
\text { MMP-13 }\end{array}$ & $\begin{array}{l}\searrow \text { MMP-13 } \\
\text {-alleviate inflammation of } \\
\text { osteoarthritis }\end{array}$ & [212] \\
\hline Resveratrol & $\begin{array}{l}\text { Animal model } \\
\text { (rabbit) }\end{array}$ & $\begin{array}{l}50,20, \text { and } \\
10 \mu \mathrm{mol} / \mathrm{kg} / \\
2 \text { weeks }\end{array}$ & $\begin{array}{l}\text { cartilage sections } \\
\text { (medial condyle) } \\
\text { synovial fluid } \\
\text { NO }\end{array}$ & $\begin{array}{l}\searrow \mathrm{NO} \\
\text {-the protective effect } \\
\text { increased with increased } \\
\text { dosage }\end{array}$ & [217] \\
\hline Resveratrol & $\begin{array}{l}\text { Clinical study } \\
30 \text { KOA patients } \\
\text { human articular } \\
\text { chondrocytes } \\
\text { (harvested from } \\
\text { osteoarthritis } \\
\text { patients) }\end{array}$ & $6.25-200 \mu \mathrm{M}$ & $\begin{array}{l}\text { chondrocytes } \\
\text { culture } \\
\text { TLR4 } \\
\text { IL-1 } \beta \text { products }\end{array}$ & $\begin{array}{l}\text {-low concentrations (up to } \\
25 \mu \mathrm{M} \text { ) promoted cell } \\
\text { proliferation, while a higher } \\
\text { concentration (50-200 } \mu \mathrm{M}) \\
\text { had no effect } \\
\text {-inhibition of TLR4/MyD88/ } \\
\text { NF-kB signaling pathway }\end{array}$ & [218] \\
\hline
\end{tabular}


Table 1. Cont

\begin{tabular}{|c|c|c|c|c|c|}
\hline Antioxidant & Type of Study & Dosage/Time & $\begin{array}{c}\text { Studied } \\
\text { Samples/Analytes }\end{array}$ & Effect & Ref. \\
\hline Chlorogenic acid & $\begin{array}{l}\text { Animal model } \\
\text { (rabbit) } \\
\text { Local injection } \\
16 \text { subjects / } \\
4 \text { controls }\end{array}$ & $\begin{array}{l}20 \mu \mathrm{M} / \\
6 \text { weeks }\end{array}$ & $\begin{array}{l}\text { anterior cruciate } \\
\text { ligament } \\
\text { transection } \\
\text { MMP-1, MMP-3, } \\
\text { MMP-13, TIMP-1 }\end{array}$ & $\begin{array}{l}\nearrow \text { TIMP-1 } \\
\searrow \text { MMP-1 } \\
\searrow \text { MMP-3 } \\
\searrow \text { MMP-13 }\end{array}$ & [219] \\
\hline $\begin{array}{l}\text { Green tea } \\
\text { polyphenol } \\
\text { epigallocatechin } \\
\text { 3-gallate }\end{array}$ & $\begin{array}{l}\text { In vitro } \\
\text { Human } \\
\text { OA cartilage }\end{array}$ & $200 \mu \mathrm{M} / 24 \mathrm{~h}$ & $\begin{array}{l}\text { OA cartilage } \\
\mathrm{COX}-2 \\
\text { iNOS } \\
\mathrm{NO}- \\
\mathrm{PGE}_{2}\end{array}$ & $\begin{array}{l}\searrow \text { COX-2 } \\
\searrow \text { iNOS } \\
\text { inhibit the production of } \\
\mathrm{NO} \text { and } \mathrm{PGE}_{2}\end{array}$ & [220] \\
\hline $\begin{array}{l}\text { Glucosamine } \\
\text { chondroitin }\end{array}$ & $\begin{array}{l}\text { Network } \\
\text { meta-analysis on } \\
\text { extremely different } \\
\text { trials } \\
\text { Bayesian model } \\
10 \text { trials / } \\
3803 \text { patients }\end{array}$ & $\begin{array}{l}0.500 \mathrm{mg} / 3 \text { time } \\
\text { per day }\end{array}$ & $\begin{array}{l}\text { pain intensity. } \\
\text {-in minimal width } \\
\text { of joint space }\end{array}$ & $\begin{array}{l}\text {-no significant decrease in } \\
\text { joint pain } \\
\text {-no measurable impact on } \\
\text { narrowing of joint space }\end{array}$ & {$[221,222]$} \\
\hline $\begin{array}{l}\text { Glucosamine } \\
\text { sulfate (crystalline) }\end{array}$ & $\begin{array}{l}\text { Long-term } \\
\text { randomized, } \\
\text { placebo-controlled } \\
\text { trial } \\
202 \text { patients }\end{array}$ & $\begin{array}{l}1.5 \mathrm{~g} / \text { day } \\
3 \text { years }\end{array}$ & $\begin{array}{l}\text { pain intensity. } \\
\text { change in minimal } \\
\text { width of joint } \\
\text { space }\end{array}$ & $\begin{array}{l}\text {-significant reduction of } \\
\text { joint structure changes } \\
\text {-clinically relevant } \\
\text { improvement of pain }\end{array}$ & {$[223]$} \\
\hline $\begin{array}{l}\text { Pomegranate } \\
\text { extract } \\
\text { (Flavonoids and } \\
\text { polyphenols) }\end{array}$ & $\begin{array}{l}\text { Animal model } \\
\text { (rat) }\end{array}$ & $\begin{array}{l}0.50 \mathrm{mg} / \mathrm{kg} \\
28 \text { days }\end{array}$ & $\begin{array}{l}\text { chondrocyte } \\
\text { culture } \\
\text { Type II } \\
\text { Collagenase } \mathrm{PGE}_{2} \\
\text { IL-1 } \beta\end{array}$ & 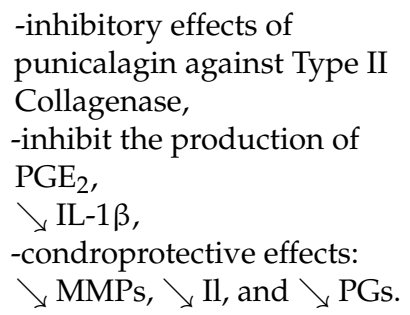 & {$[224]$} \\
\hline $\begin{array}{l}\text { Rosmarinic acid } \\
\text { (RosA } \\
\text { water-soluble } \\
\text { polyphenol, } \\
\text { isolated from } \\
\text { Rosmarinus } \\
\text { officinalis. }\end{array}$ & $\begin{array}{l}\text { Animal model } \\
\text { (rat) }\end{array}$ & $\begin{array}{l}\text { chondrocytes were } \\
\text { exposed to RosA } \\
(10,50,100 \mu \mathrm{M}) \text { for } \\
1 \mathrm{~h}\end{array}$ & $\begin{array}{l}\text { OA cartilage } \\
\text {-chondrocytes } \\
\text { culture } \\
\text { IL-1 } \beta \\
\text { MMP-1 } \\
\text { MMP-3 } \\
\text { MMP-13 } \\
\text { PGE } 2 \\
\text { iNOS } \\
\text { COX-2 }\end{array}$ & $\begin{array}{l}\text {-inhibited the IL-1 } \beta \text {-induced } \\
\text { gene expression of MMP-1, } \\
\text { MMP-3, and MMP-13 in a } \\
\text { dose-dependent manner. } \\
\searrow \text { MMP-1, MMP-3, and } \\
\text { MMP-13 in chondrocytes, } \\
\nearrow \text { type II collagen, } \\
\text { sulfated-proteoglycan, } \\
\text { and PGE } 2 \text { production, } \\
\text { inhibited the protein } \\
\text { expression of iNOS and } \\
\text { COX-2 in chondrocytes. }\end{array}$ & {$[225]$} \\
\hline
\end{tabular}

ADAMTS-5: ADAM metallopeptidase with thrombospondin type 5 motif; Coll2-1NO2- biomarker of cartilage degradation; COX-2cyclooxygenase-2; IL: interleukin; IL-1 $\beta$-Interleukin-1 beta; iNOS: inducible nitric oxide synthase; MAPK: mitogen-activated protein kinase; MMPs: matrix metalloproteinases (1,3 or 13); MKK3-mitogen-activated protein kinase-3; MyD88-Myeloid differentiation primary response protein; NO: nitric oxide; NF-KB: nuclear factor-kappa activated B cells; PGs-prostaglandines; $\mathrm{PGE}_{2}$-prostaglandin $\mathrm{E}_{2}$; RosA- Rosmarinic acid; SOD: superoxide dismutase; TIMP-1-tissue inhibitor of metalloproteinases-1; TLR4-Toll-like receptor 4. Both used arrows are symbols for increase and respetively for decrease.

\subsection{Administration of Antioxidants in $K O A$}

Nowadays, the data provided by in vitro and in vivo tests and the association between exogenous antioxidants and their metabolites in the generated therapeutic effects have made antioxidants a hot topic for research [226]. Despite the phenolic structure that allowed the elucidation of polyphenols' redox mechanisms, the direct correlation of the antioxidant effect with the beneficial effects in KOA through their metabolites is extremely deficient. 
Better documented by in vivo studies of-KOA is the suite of effects that exogenous antioxidants can cause $[216,217,219,220]$. Consequently, the results show that exogenous antioxidants contribute to the control of pain in KOA, improving the physical function of the knee joints. All these observations substantiate the conclusion that exogenous antioxidants are good candidates for adjuvant treatment or as chemical structures that can inspire the design of new drugs.

Various ROS have been identified as relevant in KOA [227], thus being potential targets for prevention and/or therapeutic purposes. In this regard, a large amount of research has been performed, resulting in exciting findings, but without being systematized.

As the ROS level is high in the context of KOA, it is recommended to follow a diet rich in fruits and vegetables with an antioxidant role or to take nutritional supplements that provide enzymes and vitamins, which can have a preventive effect [175]. Antioxidant effects resulting in benefits for the bone system have been attributed to sage extracts, which help osteoblastic differentiation [228], and to green tea [229].

Along with a protective role, a minimal reduction in pain intensity and improved joint function were associated with the consumption of strawberries, especially in obese patients with KOA [230]. Strawberries, similar to other berries [231], have antioxidant and anti-inflammatory properties due to their polyphenol content, and the effects have been supported by biochemical analysis of inflammatory markers, which exhibit lower concentrations when consuming strawberries for more extended periods of time [230]. In addition, the same effects accompanied by a reduction in edema and joint destruction are observed in the consumption of raspberries and blueberries [231,232] or of products containing resveratrol [233]. The effects of plant-derived resveratrol lead mainly to the reduction of the chondrocytes inflammation, which is produced by IL-1 [218], and limited KOA progression, as demonstrated in lab animal studies [234].

The health benefits of the antioxidant properties of flavonoids [235] and polyphenols [236] reside in their protective effects against cardiovascular diseases [237], DM, cancer [235], and in decreasing chronic inflammation [238], which encouraged the analysis of their effects in relation to KOA. Pomegranate juice has an antioxidant role and beneficial effects for KOA patients, improving pain scores and life quality. These health benefits have been demonstrated by biochemical analyses, which revealed decreased levels of MMPs and increased levels of GPx [239].

Sesame seeds also possess significant antioxidant activity, as they contain important amounts of phenolic compounds. Sesame seed products have antioxidant effects decreasing the serum values of MDA- a degradation product of lipid oxidation. The main action of sesame compounds is to reduce low-density lipoprotein (LDL)-cholesterol levels and lowering oxidative stress in patients with KOA [240]. Similar effects have been observed in overweight people taking food supplements with garlic [241] or with avocado oil and soy. Soybean and avocado oils contain campesterol, phytosterols, $\beta$-sitosterol, stigmasterol, fatty acids, and fat-soluble vitamins, which present anticatabolic properties, with a role in preventing cartilage destruction through the inhibition of the cell activity involved in this process and by stimulating the collagen production. This behavior reveals the chondroprotective role of such supplements, as their joint stiffness reduction and analgesic effects have been clinically demonstrated [242].

The Mediterranean diet has been much appreciated for its inclusion of many antioxidantcontaining foods. In older adults on a Mediterranean diet, the symptomatic forms of KOA and pain were found to be much lower [243], while combining a diet that included extravirgin olive oil with exercise was proved as a beneficial combination for cartilages and joints [244]. Olive oil is rich in active polyphenols, such as oleuropein, tyrosol, hydroxytyrosol, and oleocanthal, with important antioxidant and anti-inflammatory properties, being an important candidate in the prevention of degenerative changes [245]. The effects of oleuropein in KOA were also studied in association with curcumin or rutine (a glycoside found in citrus fruit). Less severe joint damage and decreased markers of inflammation and of cartilage degradation, such as aggrecans or prostaglandin E2, were correlated with 
their combined antioxidant action. However, no combination of these compounds could reduce serum-nitrated collagen levels (cartilage degradation marker) [246]. In this sense, it should be mentioned the extensive overview on putative antioxidant treatment strategies for KOA performed by Deligiannidou et al. [227].

Similar to chondroitin and glucosamine sulfate, some food supplements may also slow the progression of KOA [247]. These are glycosaminoglycans synthesized by chondrocytes and synovial cells, which are part of the synovial fluid and extracellular matrix. For exogenous intake, glucosamine sulfate can be extracted from crustaceans and chondroitin sulfate from animal cartilage [248]. A nonanimal chondroitin sulphate supplementation in obese patients with KOA also improved the knee function and inflammation [249]. When high concentrations of glucosamine sulphate are reached in the body, it acts by inhibiting IL-1, which participates in tissue destruction and inflammation. In vitro studies proved that glucosamine hydrochloride presents a pronounced scavenging effect on $\mathrm{O}_{2}{ }^{\bullet-}$ and HO• [250]. The antioxidative properties of chondroitin have been studied, both in vitro and in vivo [251,252]. The proposed antioxidant mechanism involves the chelation of $\mathrm{Fe}^{2+}$ and cupric ion $\left(\mathrm{Cu}^{2+}\right)$, which, as mentioned previously, are responsible for the generation of ROS. In addition, it was shown that chondroitin-4-sulfate holds higher antioxidant activity than chondroitin-6-sulfate [253]. The administration of glucosamine in certain formulas helps to better control pain, comparably to the effect of nonsteroidal anti-inflammatory medication, by slowing down the pathology progression and decreasing the need to perform arthroplasties, even a few years after stopping the treatment [254].

Certain herbs and even spices can have analgesic effects or improve joint functions, as highlighted by some reviewed data or multicenter studies [248,255]. Oral administration of such plants at specific doses led to decreased serum levels of MDA, cartilage oligomeric matrix protein, MPO, and IL-1 $\beta$. On the other hand, it resulted in higher levels of SOD [132]. In addition to plant-based foods that have a beneficial role in balancing oxidative stress, antioxidant peptides from eggs act preventively in this regard by inactivating ROS, eliminating free radicals, reducing hydroperoxides, and chelating the pro-oxidative ions of transition metals [256].

To date, 710 antioxidant proteins are known; most of which (458) come from eukaryotes, 221 originate from bacteria, 28-from archaea, and three are viral [257]. Other perspectives for developing therapeutic options are offered by the improved heterologous expression of antioxidant enzymes derived from fungi, which are thermostable [258]. These have been called thermozymes and can be active at temperatures between 60 and $125^{\circ} \mathrm{C}$. In addition, they easily adapt to $\mathrm{pH}$ variations and have compact oligomers, increased stress resistance, and lifespan [259].

The protective mechanism against $\mathrm{H}_{2} \mathrm{O}_{2}$-induced ROS in human chondrocytes could be also provided by delphinidin. This antioxidant may have therapeutic potential for KOA by activating cytoprotective autophagy [260].

Moreover, the approach involving dietotherapy with foods having antioxidant effects and monitoring the redox status through biomarker levels is also important in the case of other pathologies, with high prevalence in geriatric patients [261].

\section{Conclusions}

KOA is a chronic multifactorial pathology, predominantly characteristic of older adults. It is a significant public health problem for which only symptomatic therapy is available.

The current review emphasizes the importance of redox balance analysis. Thus, new individualized therapeutic perspectives are being developed to reduce oxidative stress levels in the human body, in correlation with the serum dosages of antioxidant and oxidative markers to maintain the redox balance.

Elucidating the oxidative stress generation mechanisms and the action mechanism of various antioxidants opens many possibilities in preventing and treating diseases associated with oxidative stress, especially in geriatric patients, with KOA being just one of the many pathologies associated with it. 
This review highlights the significance of redox species and their imbalance, which can trigger oxidative stress, generating specific diseases. New therapeutic approaches to diseases associated with oxidative stress are also reviewed. It is worth mentioning that the specific benefits of an antioxidant-rich diet should be thoughtfully and systematically evaluated. It might provide an easy and economical way to treat KOA.

The reliability of the present review is based on the accuracy of the analyzed studies. There have been some reports of poorly controlled randomized clinical trials without any individual identification or isolation of the efficacious compounds, as well as a lack of uniformity in diagnosis. Such problems engender the limitations of the current review, stemming from the lack of pooled analysis or meta-analysis. The review emphasizes the need for high-quality randomized clinical studies using appropriate subjects with standardized outcome reports.

Author Contributions: Conceptualization, E.M.C., N.B.T. and E.E.T.; methodology, V.M., and A.F.; validation, E.E.T., K.S., I.I., V.A. and C.M.; formal analysis, N.B.T. and A.F.; investigation, N.B.T., I.I, E.M.C. and E.E.T.; resources, E.M.C., K.S., V.M., A.F. and E.E.T.; writing-original draft preparation, E.M.C., N.B.T., A.F. and V.M.; writing-review and editing, E.E.T., N.B.T., A.F. and K.S.; supervision, V.A. and E.M.C. All authors have read and agreed to the published version of the manuscript.

Funding: The authors acknowledge and are grateful for the financial support from a grant of Ministry of Research and Innovation, CNCS-UEFISCDI, project number PN-III-P4-ID-PCCF-20160050, within PNCDI III.

Acknowledgments: The authors acknowledge the support of the COST Action CA16112, NutRedOx, which facilitated interactions over the presented work. Review within the European collaborative project CA COST 16112. E.M.C., E.E.T., V.M., I.I., and S.K. acknowledge the support of COST Action supported by COST (European Cooperation in Science and Technology) that made possible their cooperation. This work was also supported by a grant from the Romanian Ministry of Research and Innovation, CCCDI-UEFISCDI, project number PN-III-P1-1.2-PCCDI-2017-0697/ 13PCCDI/2018, within PNCDI III.

Conflicts of Interest: The authors declare no conflict of interest.

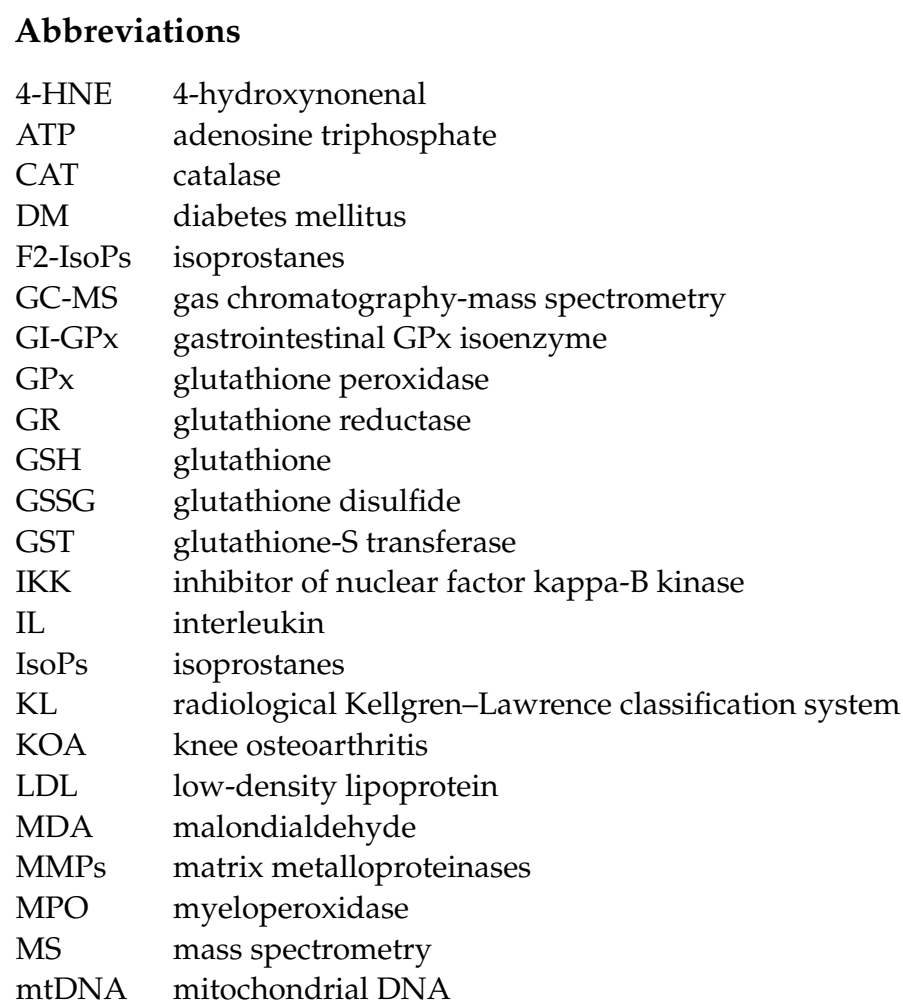




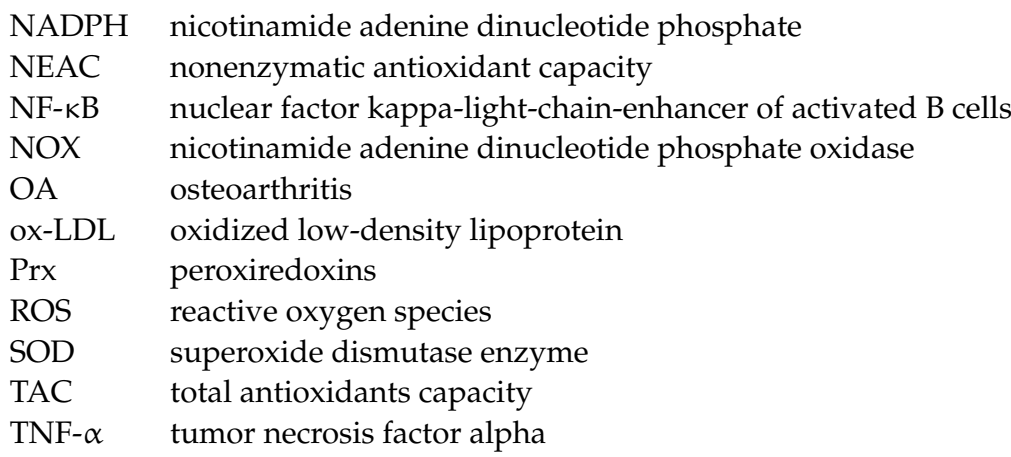

\section{References}

1. Chen, A.; Gupte, C.; Akhtar, K.; Smith, P.; Cobb, J. The global economic cost of osteoarthritis: How the UK compares. Arthritis 2012, 698709. [CrossRef]

2. $\quad$ Spinoso, D.H.; Bellei, N.C.; Marques, N.R.; Navega, T.M. Quadriceps muscle weakness influences the gait pattern in women with knee osteoarthritis. Adv. Rheumatol. 2018, 58. [CrossRef]

3. Losina, E.; Weinstein, A.M.; Reichmann, W.M.; Burbine, S.A.; Solomon, D.H.; Daigle, M.E.; Rome, B.N.; Chen, S.P.; Hunter, D.J.; Suter, L.G. Lifetime risk and age at diagnosis of symptomatic knee osteoarthritis in the US. Arthritis Care Res. 2013, 65, 703-711. [CrossRef]

4. MacKay, C.; Badley, E.M.; Jaglal, S.B.; Sale, J.; Davis, A.M. We're all looking for solutions: A qualitative study of the management of knee symptoms. Arthritis Care Res. 2014, 66, 1033-1040. [CrossRef]

5. Wallace, I.J.; Worthington, S.; Felson, D.T.; Jurmanin, R.D.; Wren, K.T.; Maijanen, H.; Woods, R.J.; Lieberman, D.E. Knee osteoarthritis has doubled in prevalence since the mid-20th century. Proc. Natl. Acad. Sci. USA 2017, 114, 9332-9336. [CrossRef] [PubMed]

6. Kurtz, S.M.; Lau, E.; Ong, K.; Zhao, K.; Kelly, M.; Bozic, K.J. Future young patient demand for primary and revision joint replacement: National projections from 2010 to 2030. Clin. Orthop Relat. Res. 2009, 467, 2606-2612. [CrossRef]

7. Ackerman, I.N.; Bohensky, M.A.; Zomer, E.; Tacey, M.; Gorelik, A.; Brand, C.A.; de Steiger, R. The projected burden of primary total knee and hip replacement for osteoarthritis in Australia to the year 2030. BMC Musculoskelet. Disord. 2019, 20. [CrossRef] [PubMed]

8. Turkiewicz, A.; Petersson, I.F.; Bjork, J.; Hawker, G.; Dahlberg, L.E.; Lohmander, L.S.; Englund, M. Current and future impact of osteoarthritis on healthcare: A population-based study with projections to year 2032. Osteoarthr. Cartil. 2014, 22, 1826-1832. [CrossRef] [PubMed]

9. Roos, E.M.; Arden, N.K. Strategies for the prevention of knee osteoarthritis. Nat. Rev. Rheumatol. 2016, 12, 92-101. [CrossRef]

10. Ziskoven, C.; Jäger, M.; Kircher, J.; Patzer, T.; Bloch, W.; Brixius, K.; Krauspe, R. Physiology and pathophysiology of nitrosative and oxidative stress in osteoarthritic joint destruction. Can. J. Physiol. Pharmacol. 2011, 89, 455-466. [CrossRef]

11. Prasad, A.; Balukova, A.; Pospíšil, P. Triplet excited carbonyls and singlet oxygen formation during oxidative radical reaction in skin. Front. Physiol. 2018, 9, 1109. [CrossRef] [PubMed]

12. Liguori, I.; Russo, G.; Curcio, F.; Bulli, G.; Aran, L.; Della-Morte, D.; Gargiulo, G.; Testa, G.; Cacciatore, F.; Bonduce, D.; et al. Oxidative stress, aging, and diseases. Clin. Interv. Aging 2018, 13, 757-772. [CrossRef] [PubMed]

13. Lindsay, A.; McCourt, P.M.; Karachunski, P.; Lowe, D.A.; Evasti, J.M. Xanthine oxidase is hyper-active in Duchenne muscular dystrophy. Free Radic. Biol. Med. 2018, 129, 364-371. [CrossRef] [PubMed]

14. Bolduc, J.A.; Collins, J.A.; Loeser, R.F. Reactive oxygen species, aging and articular cartilage homeostasis. Free Radic. Biol. Med. 2019, 132, 73-82. [CrossRef]

15. Ray, P.D.; Huang, B.W.; Tsuji, Y. Reactive oxygen species (ROS) homeostasis and redox regulation in cellular signaling. Cell. Signal. 2012, 24, 981-990. [CrossRef]

16. Sies, H. Oxidative stress: A concept in redox biology and medicine. Redox Biol. 2015, 4, 180-183. [CrossRef]

17. Kurutas, E.B. The importance of antioxidants which play the role in cellular response against oxidative/nitrosative stress: Current state. Nutr. J. 2016, 15. [CrossRef]

18. Turrens, J.F. Mitochondrial formation of reactive oxygen species. J. Physiol. 2003, 552, 335-344. [CrossRef]

19. Kohen, R.; Nyska, A. Oxidation of biological systems: Oxidative stress phenomena, antioxidants, redox reactions, and methods for their quantification. Toxicol. Pathol. 2002, 30, 626-650. [CrossRef] [PubMed]

20. Lü, J.M.; Lin, P.H.; Yao, Q.; Chen, C. Chemical and molecular mechanisms of antioxidants: Experimental approaches and model systems. J. Cell. Mol. Med. 2010, 14. [CrossRef]

21. Sies, H. Hydrogen peroxide as a central redox signaling molecule in physiological oxidative stress: Oxidative eustress. Redox Biol. 2017, 11, 613-619. [CrossRef]

22. Forman, H.J.; Bernardo, A.; Davies, K.J. What is the concentration of hydrogen peroxide in blood and plasma? Arch. Biochem. Biophys. 2016, 6, 48-53. [CrossRef] [PubMed]

23. Lipinski, B. Hydroxyl radical and its scavengers in health and disease. Oxid. Med. Cell. Longev. 2011. [CrossRef] [PubMed] 
24. Lepetsos, P.; Papavassiliou, A.G. ROS/oxidative stress signaling in osteoarthritis. Biochim. Acta Biomembr. 2016, 1862, 576-591. [CrossRef] [PubMed]

25. Checa, J.; Aran, J.M. Reactive Oxygen Species: Drivers of Physiological and Pathological Processes. J. Inflamm. Res. 2020, 13, 1057-1073. [CrossRef]

26. Ansari, M.Y.; Ahmad, N.; Haqqi, T. Oxidative stress and inflammation in osteoarthritis pathogenesis: Role of polyphenols. Biomed. Pharmacother. 2020, 129. [CrossRef]

27. Baradaran, A.; Nasri, H.; Rafieian-Kopaei, M. Oxidative stress and hypertension: Possibility of hypertension therapy with antioxidants. J. Res. Med. Sci. 2014, 119, 358-367.

28. Wang, K.; Dong, Y.; Liu, J.; Qian, L.; Wang, T.; Gao, X.; Wang, K.; Zhou, L. Effects of REDOX in regulating and treatment of metabolic and inflammatory cardiovascular diseases. Oxid. Med. Cell. Longev. 2020. [CrossRef]

29. Pantea Stoian, A.; Mitrofan, G.; Colceag, F.; Serafinceanu, C.; Eftimie Totu, E.; Mocanu, V.; Mănuc, D.; Cărăuşu, M.E. Oxidative stress applied in Diabetes Mellitus-A new paradigm. Proceedings 2019, 11, 1007. [CrossRef]

30. Ardeleanu, V.; Toma, A.; Pafili, K.; Papanas, N.; Motofei, I.; Diaconu, C.C.; Rizzo, M.; Stoian, A.P. Current pharmacological treatment of painful diabetic neuropathy: A narrative review. Medicina 2020, 56, 25. [CrossRef]

31. Andrisic, L.; Dudzik, D.; Barbas, C.; Milkovic, L.; Grune, T.; Zarkovic, N. Short overview on metabolomics approach to study pathophysiology of oxidative stress in cancer. Redox Biol. 2018, 14, 47-58. [CrossRef]

32. Percário, S.; da Silva Barbosa, A.; Varela, E.L.P.; Gomes, A.R.Q.; Ferreira, M.E.S.; Moreira, T.N.A.; Dolabela, M.F. Oxidative stress in parkinson's disease: Potential benefits of antioxidant supplementation. Oxid. Med. Cell. Longev. 2020. [CrossRef]

33. Degtyareva, N.P.; Saini, N.; Sterling, J.F.; Placentra, V.C.; Klimczak, L.J.; Gordenin, D.A.; Doetsch, P.W. Mutational signatures of redox stress in yeast single-strand DNA and of aging in human mitochondrial DNA share a common feature. PLoS Biol. 2019, 17. [CrossRef]

34. Ighodaro, O.M.; Ainloye, O.A. First line defence antioxidants-superoxide dismutase (SOD), catalase (CAT) and glutathione peroxidase (GPX): Their fundamental role in the entire antioxidant defence grid. Alexandria J. Med. 2018, 54, 287-293. [CrossRef]

35. Scott, J.L.; Gabrielides, C.; Davidson, R.K.; Swingler, T.E.; Clark, I.M.; Walis, G.A.; Boot-Handford, R.P.; Kirkwood, T.B.L.; Taylor, R.W.; Young, D.A. Scott, J.L.; et al. Superoxide dismutase downregulation in osteoarthritis progression and end stage disease. Ann. Rheum. Dis. 2010, 69, 1502-1510. [CrossRef]

36. Shi, Y.; Hu, X.; Cheng, J.; Zhang, X.; Zhao, F.; Shi, W.; Ren, B.; Yu, H.; Yang, P.; Li, Z.; et al. A small molecule promotes cartilage extracellular matrix generation and inhibits osteoarthritis development. Nat. Commun. 2019, 10. [CrossRef] [PubMed]

37. Mao, C.; Yuan, J.Q.; Lv, Y.B.; Gao, X.; Yin, Z.X.; Kraus, V.B.; Luo, J.S.; Chei, C.L.; Matchar, D.B.; Zeng, Y. Associations between superoxide dismutase, malondialdehyde and all-cause mortality in older adults: A community-based cohort study. BMC Geriatr. 2019, 19. [CrossRef]

38. Sepasi Tehrani, H.; Moosavi-Movahedi, A.A. Catalase and its mysteries. Prog. Biophys. Mol. Biol. 2018, 140. [CrossRef]

39. Collins, J.A.; Wood, S.T.; Nelson, K.J.; Rowe, M.A.; Carlson, C.S.; Chubinskaya, S.; Poole, L.B.; Furdui, C.M.; Loeser, R.F. Oxidative stress promotes peroxiredoxin hyperoxidation and attenuates pro-survival signaling in aging chondrocytes. J. Biol. Chem. 2016, 291, 6641-6654. [CrossRef] [PubMed]

40. Olszewska-Słonina, D.M.; Matewski, D.; Drewa, G.; Woźniak, A.; Czajkowski, R.; Rajewski, P.; Olszewski, K.J.; Zegarska, B. Oxidative equilibrium in the prophylaxis of degenerative joint changes: An analysis of pre- and postoperative activity of antioxidant enzymes in patients with hip and knee osteoarthritis. Med. Sci. Monit. 2010, 16, CR236-CR238. [PubMed]

41. Arthur, J.R. The glutathione peroxidases. Cell. Mol. Life Sci. 2000, 57, 1825-1835. [CrossRef] [PubMed]

42. Brigelius-Flohé, R. Tissue-specific functions of individual glutathione peroxidases. Free Radic. Biol. Med. 1999, 27, 951-965. [CrossRef]

43. Sobotta, M.C.; Liou, W.; Stöcker, S.; Talwar, D.; Oehler, M.; Ruppert, T.; Scharf, A.N.; Dick, T.P. Peroxiredoxin-2 and STAT3 form a redox relay for $\mathrm{H} 2 \mathrm{O} 2$ signaling. Nat. Chem. Biol. 2015, 11, 64-70. [CrossRef] [PubMed]

44. Lushchak, V.I. Glutathione homeostasis and functions: Potential targets for medical interventions. J. Amin. Acids 2012. [CrossRef]

45. Pisoschi, A.M.; Pop, A. The role of antioxidants in the chemistry of oxidative stress: A review. Eur. J. Med. Chem. 2015, 97, 55-74. [CrossRef]

46. Farhat, Z.; Browne, R.W.; Bonner, M.R.; Tian, L.; Deng, F.; Swanson, M.; Mu, L. How do glutathione antioxidant enzymes and total antioxidant status respond to air pollution exposure? Environ. Int. 2018, 112, 287-293. [CrossRef]

47. Krinsky, N.I.; Johnson, E.J. Carotenoid actions and their relation to health and disease. Mol. Asp. Med. 2005, 26, 459-516. [CrossRef]

48. El-Agamey, A.; Lowe, G.M.; McGarvey, D.J.; Mortensen, A.; Phillip, D.M.; Truscott, T.G.; Young, A.J. Carotenoid radical chemistry and antioxidant/pro-oxidant properties. Arch. Biochem. Biophys. 2004, 430, 37-48. [CrossRef]

49. Ripani, U.; Manzarbeitia-Arroba, P.; Guijarro-Leo, S.; Urrutia-Graña, J.; De Masi-De Luca, A. Vitamin C May Help to Reduce the Knee's Arthritic Symptoms. Outcomes Assessment of Nutriceutical Therapy. Med. Arch. 2019, 73, 173-177. [CrossRef] [PubMed]

50. Blackburn, A.R., 2nd; Hamrick, M.W.; Chutkan, N.; Sangani, R.; Waller, J.L.; Corpe, R.; Prasad, P.D.; Isales, C.M.; Ganapathy, V.; Fulzele, S. Comparative analysis of sodium coupled vitamin $C$ transporter 2 in human osteoarthritis grade 1 and grade 3 tissues. BMC Musculoskelet. Disord. 2014, 15. [CrossRef]

51. Nabzdyk, C.S.; Bittner, E.A. Vitamin C in the critically ill-indications and controversies. World J. Crit. Care Med. 2018, 7, 52-61. [CrossRef] 
52. Chin, K.Y.; Ima-Nirwana, S. The Role of Vitamin E in preventing and treating osteoarthritis- a review of the current evidence. Front. Pharmacol. 2018, 9. [CrossRef]

53. Peh, H.Y.; Tan, W.S.; Liao, W.; Wong, W.S. Vitamin E therapy beyond cancer: Tocopherol versus tocotrienol. Pharmacol. Ther. 2016, 162, 152-169. [CrossRef] [PubMed]

54. Aggarwal, B.B.; Sundaram, C.; Prasad, S.; Kannappan, R. Tocotrienols, the vitamin E of the 21st century: Its potential against cancer and other chronic diseases. Biochem. Pharmacol. 2010, 80, 1613-1631. [CrossRef] [PubMed]

55. Chin, K.Y.; Ima-Nirwana, S. The effects of $\alpha$-tocopherol on bone: A double-edged sword? Nutrients 2014, 6, 1424-1441. [CrossRef]

56. Ahmad, N.S.; Khalid, B.A.; Luke, D.A.; Ima Nirwana, S. Tocotrienol offers better protection than tocopherol from free radicalinduced damage of rat bone. Clin. Exp. Pharmacol. Physiol. 2005, 32, 761-770. [CrossRef]

57. Maniam, S.; Mohamed, N.; Shuid, A.N.; Soelaiman, I.N. Palm tocotrienol exerted better antioxidant activities in bone than alpha-tocopherol. Basic Clin. Pharmacol. Toxicol. 2008, 103, 55-60. [CrossRef]

58. Schmelzer, C.; Lindner, I.; Rimbach, G.; Niklowitz, P.; Menke, T.; Döring, F. Functions of coenzyme Q10 in inflammation and gene expression. Biofactors 2008, 32, 179-183. [CrossRef]

59. Lee, J.; Hong, Y.S.; Jeong, J.H.; Yang, E.J.; Jhun, J.Y.; Park, M.K.; Jung, Y.O.; Min, J.K.; Kim, H.Y.; Park, S.H.; et al. Coenzyme Q10 ameliorates pain and cartilage degradation in a rat model of osteoarthritis by regulating nitric oxide and inflammatory cytokines. PLoS ONE 2013, 8. [CrossRef]

60. Lai, H.Y.; Chang, H.T.; Lee, Y.L.; Hwang, S.J. Association between inflammatory markers and frailty in institutionalized older men. Maturitas 2014, 79, 329-333. [CrossRef] [PubMed]

61. Musumeci, G.; Castrogiovanni, P.; Trovato, F.M.; Di Giunta, A.; Loreto, C.; Castorina, S. Microscopic and macroscopic anatomical features in healthy and osteoarthritic knee cartilage. Anatomy 2013, 1. [CrossRef]

62. Hui, W.; Young, D.A.; Rowan, A.D.; Xu, X.; Cawston, T.E.; Proctor, C.J. Oxidative changes and signaling pathways are pivotal in initiating age-related changes in articular cartilage. Ann. Rheum. Dis. 2016, 75, 449-458. [CrossRef]

63. Mobasheri, A.; Matta, C.; Zákány, R.; Musumeci, G. Chondrosenescence: Definition, hallmarks and potential role in the pathogenesis of osteoarthritis. Maturitas 2015, 80, 237-244. [CrossRef]

64. Davies, J.M.S.; Cillard, J.; Friguet, B.; Friguet, B.; Cadenas, E.; Cadet, J.; Cayce, R.; Fishman, A.; Liao, D.; Bulteau, A.L.; et al. The oxygen paradox, the french paradox, and age-related diseases. GeroScience 2017, 39, 499-550. [CrossRef] [PubMed]

65. De Rezende, M.U.; de Campos, G.C. Is osteoarthritis a mechanical or inflammatory disease? Rev. Bras. Ortop. $2013,48,471$. [CrossRef] [PubMed]

66. Chung, H.Y.; Kim, D.H.; Lee, E.K.; Chung, S.; Lee, B.; Seo, A.Y.; Chung, J.H.; Jung, Y.S.; Im, E. Redefining chronic inflammation in aging and age-related diseases: Proposal of the senoinflammation concept. Aging Dis. 2019, 10, 367-382. [CrossRef]

67. Beavers, K.M.; Beavers, D.P.; Newman, J.J.; Anderson, A.M.; Loeser Jr, R.F.; Nicklas, B.J.; Lyles, M.F.; Miller, G.D.; Mihalko, S.L.; Messier, S.P. Effects of total and regional fat loss on plasma CRP and IL-6 in overweight and obese, older adults with knee osteoarthritis. Osteoarthr. Cartil. 2015, 23, 249-256. [CrossRef]

68. Minguzzi, M.; Cetrullo, S.; D'Adamo, S.; Silvestri, Y.; Flamigni, F.; Borzì, R.M. Emerging players at the intersection of chondrocyte loss of maturational arrest, oxidative stress, senescence and low-grade inflammation in osteoarthritis. Oxid. Med. Cell. Longev. 2018, 1-17. [CrossRef]

69. Olivotto, E.; Otero, M.; Marcu, K.B.; Goldring, M.B. Pathophysiology of osteoarthritis: Canonical NF- $\mathrm{B}$ /IKK $\beta$-dependent andkinase-independent effects of IKK $\alpha$ in cartilage degradation and chondrocyte differentiation. RMD Open 2015, 1. [CrossRef] [PubMed]

70. Ma, M.W.; Wang, J.; Zhang, Q.; Wang, R.; Dhandapani, K.M.; Vadlamudi, R.K.; Brann, D.W. NADPH oxidase in brain injury and neurodegenerative disorders. Mol. Neurodegener. 2017, 12, 7. [CrossRef]

71. Drevet, S.; Gavazzi, G.; Grange, L.; Dupuy, C.; Lardy, B. Reactive oxygen species and NADPH oxidase 4 involvement in osteoarthritis. Exp. Gerontol. 2018, 111, 107-117. [CrossRef] [PubMed]

72. Grange, L.; Nguyen, M.V.; Lardy, B.; Derouazi, M.; Campion, Y.; Trocme, C.; Paclet, M.H.; Gaudin, P.; Morel, F. NAD(P)H oxidase activity of Nox4 in chondrocytes is both inducible and involved in collagenase expression. Antioxid. Redox. Signal. 2006, 8, 1485-1496. [CrossRef] [PubMed]

73. Burtenshaw, D.; Hakimjavadi, R.; Redmond, E.M.; Cahi, P.A. Nox, reactive oxygen species and regulation of vascular cell fate. Antioxidants 2017, 6, 90. [CrossRef]

74. Henrotin, Y.; Kurz, B.; Aigner, T. Oxygen and reactive oxygen species in cartilage degradation: Friends or foes? Osteoarthr. Cart. 2005, 13, 643-654. [CrossRef]

75. Van Lent, P.L.; Nabbe, K.C.; Blom, A.B.; Sloetjes, A.; Holthuysen, A.E.; Kolls, J.; Van De Loo, F.A.; Holland, S.M.; Van Den Berg, W.B. NADPH-oxidase-driven oxygen radical production determines chondrocyte death and partly regulates metalloproteinasemediated cartilage matrix degradation during interferon- $\gamma$-stimulated immune complex arthritis. Arthritis Res. Ther. 2005, 7, 885-895. [CrossRef]

76. Wolff, K.J.; Ramakrishnan, P.S.; Brouillette, M.J.; Journot, B.J.; Mckinley, T.O.; Buckwalter, J.A.; Martin, J.A. Mechanical stress and ATP synthesis are coupled by mitochondrial oxidants in articular cartilage. J. Orthop. Res. 2012, 31, 191-196. [CrossRef]

77. Kühn, K.; Shikhman, A.R.; Lotz, M. Role of nitric oxide, reactive oxygen species, and p38 MAP kinase in the regulation of human chondrocyte apoptosis. J. Cell. Physiol. 2003, 197, 379-387. [CrossRef] 
78. Zahan, O.M.; Serban, O.; Gherman, C.F.D. The evaluation of oxidative stress in osteoarthritis. Med. Pharm. Rep. 2020, 93, 12-22. [CrossRef]

79. Frenkel, S.R.; Clancy, R.M.; Ricci, J.L.; Di Cesare, P.E.; Rediske, J.J.; Abramson, S.B. Effects of nitric oxide on chondrocyte migration, adhesion, and cytoskeletal assembly. Arthritis Rheum. 1996, 39, 1905-1912. [CrossRef] [PubMed]

80. Johnson, K.; Jung, A.; Murphy, A.; Andreyev, A.; Dykens, J.; Terkeltaub, R. Mitochondrial oxidative phosphorylation is a downstream regulator of nitric oxide effects on chondrocyte matrix synthesis and mineralization. Arthritis Rheumatol. 2000, 43, 1560-1570. [CrossRef]

81. Koike, M.; Nojiri, H.; Ozawa, Y.; Watanabe, K.; Muramatsu, Y.; Kaneko, H.; Morikawa, D.; Kobayashi, K.; Saita, Y.; Sasho, T.; et al. Mechanical overloading causes mitochondrial superoxide and SOD2 imbalance in chondrocytes resulting in cartilage degeneration. Sci. Rep. 2015, 5. [CrossRef]

82. Erturk, C.; Altay, M.A.; Selek, S.; Kocyigit, A. Paraoxonase-1 activity and oxidative status in patients with knee osteoarthritis and their relationship with radiological and clinical parameters. Scand. J. Clin. Lab. Invest. 2012, 72, 433-439. [CrossRef] [PubMed]

83. Altindag, O.; Erel, O.; Aksoy, N.; Selek, S.; Celik, H.; Karaoglanoglu, M. Increased oxidative stress and its relation with collagen metabolism in knee osteoarthritis. Rheumatol. Int. 2006, 27, 339-344. [CrossRef]

84. Ostalowska, A.; Birkner, E.; Wiecha, M.; Kasperczyk, S.; Kasperczyk, A.; Kapolka, D.; Zon-Giebel, A. Lipid peroxidation and antioxidant enzymes in synovial fluid of patients with primary and secondary osteoarthritis of the knee joint. Osteoarthr. Cart. 2006, 14, 139-145. [CrossRef]

85. Portal-Núñez, S.; Esbrit, P.; Alcaraz, M.J.; Largo, R. Oxidative stress, autophagy, epigenetic changes and regulation by miRNAs as potential therapeutic targets in osteoarthritis. Biochem. Pharmacol. 2016, 108, 1-19. [CrossRef] [PubMed]

86. Hardin, J.A.; Cobelli, N.; Santambrogio, L. Consequences of metabolic and oxidative modifications of cartilage tissue. Nat. Rev. Rheumatol. 2015, 11, 521-529. [CrossRef] [PubMed]

87. Loeser, R.F.; Goldring, S.R.; Scanzello, C.R.; Goldring, M.B. Osteoarthritis: A disease of the joint as an organ. Arthritis Rheumatol. 2012, 64, 1697-1707. [CrossRef] [PubMed]

88. Karan, A.; Karan, M.A.; Vural, P.; Erten, N.; Tascioglu, C.; Aksoy, C.; Canbaz, M.; Oncel, A. Synovial fluid nitric oxide levels in patients with knee osteoarthritis. Clin. Rheumatol. 2003, 22, 397-399. [CrossRef]

89. Nemirovskiy, O.V.; Radabaugh, M.R.; Aggarwal, P.; Funckes-Shippy, C.L.; Mnich, S.J.; Meyer, D.M.; Sunyer, T.; Rodney Mathews, W.; Misco, T.P. Plasma 3-nitrotyrosine is a biomarker in animal models of arthritis: Pharmacological dissection of iNOS' role in disease. Nitric Oxide 2008, 20, 150-156. [CrossRef]

90. Shen, C.; Yan, J.; Erkocak, O.F.; Zheng, X.F.; Chen, X.D. Nitric oxide inhibits autophagy via suppression of JNK in meniscal cells. Rheumatology 2014, 53, 1022-1033. [CrossRef]

91. Ioan-Facsinay, A.; Kloppenburg, M. An emerging player in knee osteoarthritis: The infrapatellar fat pad. Arthritis Res. Ther. 2013, 15, 225. [CrossRef] [PubMed]

92. Jones, G. What's new in osteoarthritis pathogenesis? Intern. Med. J. 2016, 46, 229-236. [CrossRef] [PubMed]

93. Johnson, V.L.; Hunter, D.J. The epidemiology of osteoarthritis. Best Pr. Res. Clin. Rheumatol. 2014, 28, 5-15. [CrossRef]

94. Toh, W.S.; Brittberg, M.; Farr, J.; Foldager, C.B.; Gomoll, A.H.; Hui, J.H.; Richardson, J.B.; Roberts, S.; Spector, M. Cellular senescence in aging and osteoarthritis. Acta Orthop. 2016, 87, 6-14. [CrossRef]

95. Kenney, M.C.; Chwa, M.; Atilano, S.R.; Pavlis, J.M.; Falatoonzadeh, P.; Ramirez, C.; Malik, D.; Hsu, T.; Woo, G.; Soe, K.; et al Mitochondrial DNA variants mediate energy production and expression levels for CFH, C3 and EFEMP1 genes: Implications for age-related macular degeneration. PLoS ONE 2013, 8, e54339. [CrossRef] [PubMed]

96. Fernandez-Moreno, M.; Soto-Hermida, A.; Vasquez-Mosquera, M.E.; Cortes-Preira, E.; Relano, S.; Hermida-Gomez, S.; Pertega, S.; Oreiro-Villar, N.; Fernandez-Lopez, C.; Garesse, R. Mitochondrial DNA haplogroups influence the risk of incident knee osteoarthritis in OAI and CHECK chorts. A meta-analysis and functional study. Ann. Rheum. Dis. 2017, 76, 1114-1122. [CrossRef]

97. Guilak, F.; Fermor, B.; Keefe, F.J.; Kraus, V.B.; Olson, S.A.; Pisetsky, D.S.; Setton, L.A.; Weinberg, J.B. The role of biomechanics and inflammation in cartilage injury and repair. Clin. Orthop. Relat. Res. 2004, 423, 17-26. [CrossRef]

98. Schieber, M.; Chandel, N.S. ROS function in redox signaling and oxidative stress. Curr. Biol. 2014, 24, R453-R462. [CrossRef]

99. Gavriilidis, C.; Miwa, S.; von Zglinicki, T.; Taylor, R.W.; Young, D.A. Mitochondrial dysfunction in osteoarthritis is associated with down-regulation of superoxide dismutase 2. Arthritis Rheum. 2013, 65, 378-387. [CrossRef]

100. Liu, H.; Li, Z.; Cao, Y.; Cui, Y.; Yang, X.; Meng, Z.; Wang, R. Effect of chondrocyte mitochondrial dysfunction on cartilage degeneration: A possible pathway for osteoarthritis pathology at the subcellular level. Mol. Med. Rep. 2019, 20, 3308-3316. [CrossRef]

101. López-Otín, C.; Blasco, M.A.; Partridge, L.; Serrano, M.; Kroemer, G. The hallmarks of aging. Cell 2013, 153, 1194-1217. [CrossRef] [PubMed]

102. Gao, J.; Feng, Z.; Wang, X.; Zeng, M.; Liu, J.; Han, S.; Xu, J.; Chen, L.; Cao, K.; Long, J.; et al. SIRT3/SOD2 maintains osteoblast differentiation and bone formation by regulating mitochondrial stress. Cell Death Differ. 2018, 25, 229-240. [CrossRef]

103. Kawanishi, S.; Ohnishi, S.; Ma, N.; Hiraku, Y.; Murata, M. Crosstalk between DNA Damage and inflammation in the multiple steps of carcinogenesis. Int. J. Mol. Sci. 2017, 18, 1808. [CrossRef]

104. Passos, J.F.; Saretzki, G.; von Zglinicki, T. DNA damage in telomeres and mitochondria during cellular senescence: Is there a connection? Nucleic Acids Res. 2007, 35, 7505-7513. [CrossRef] [PubMed] 
105. Li, J.; Pei, M. Cell senescence: A challenge in cartilage engineering and regeneration. Tissue Eng. Part B Rev. $2012,18,270-287$. [CrossRef] [PubMed]

106. Almeida, M.; O’Brien, C.A. Basic biology of skeletal aging: Role of stress response pathways. J. Gerontol. A Biol. Sci. Med. Sci. 2013, 68, 1197-1208. [CrossRef]

107. Tian, Y.; Ma, X.; Yang, C.; Su, P.; Yin, C.; Qian, A.R. The impact of oxidative stress on the bone system in response to the space special environment. Int. J. Mol. Sci. 2017, 18, 2132. [CrossRef] [PubMed]

108. Anghel, L.; Sascau, R.; Radu, R.; Statescu, C. From classical laboratory parameters to novel biomarkers for the diagnosis of venous thrombosis. Int. J. Mol. Sci. 2020, 21, 1920. [CrossRef]

109. Frijhoff, J.; Winyard, P.G.; Zarkovic, N.; Davies, S.S.; Stocker, R.; Cheng, D.; Knight, A.R.; Taylor, E.L.; Oettrich, J.; Ruskovska, T. Clinical relevance of biomarkers of oxidative stress. Antioxid. Redox Signal 2015, 23, 1144-1170. [CrossRef]

110. Niedzielska, E.; Smaga, I.; Gawlik, M.; Moniczewski, A.; Stankowicz, P.; Pera, J.; Filip, M. Oxidative stress in neurodegenerative diseases. Mol. Neurobiol. 2016, 53, 4094-4125. [CrossRef]

111. Rivara, M.B.; Yeung, C.K.; Robinson-Cohen, C.; Phillips, B.R.; Ruzinski, J.; Rock, D.; Linke, L.; Shen, D.D.; Ikizler, T.A.; Himmelfarb, J. Effect of coenzyme Q10on biomarkers of oxidative stress and cardiac function in hemodialysis patients: The CoQ10 biomarker trial. Am. J. Kidney Dis. 2017, 69, 389-399. [CrossRef] [PubMed]

112. Nechita, A.; Dinu, C.; Ciubara, A.B.; Raftu, G.; Ancuta, C. Free radicals and antioxidants in ankylosing spondylitis. Rev. Chim. 2018, 69, 3534-3637. [CrossRef]

113. Ceasovschih, A.; Sorodoc, V.; Onofrei Aursulesei, V.; Tesloianu, D.; Tuchilus, C.; Anisie, E.; Petris, A.; Statescu, C.; Jaba, E.; Stoica, A. Biomarker utility for peripheral artery disease diagnosis in real clinical practice: A prospective study. Diagnostics 2020, 10, 723. [CrossRef] [PubMed]

114. Kaur, J.; Politis, C.; Jacobs, R. Salivary 8-hydroxy-2-deoxyguanosine, malondialdehyde, vitamin C, and vitamin E in oral pre-cancer and cancer: Diagnostic value and free radical mechanism of action. Clin. Oral. Investig. 2016, 20, 315-319. [CrossRef]

115. Yildirim, Z.; Bozkurt, B.; Ozol, D.; Armutcu, F.; Akgedik, R.; Karamanli, H.; Kizilirmak, D.; İkizek, M. Increased exhaled 8-Isoprostane and Interleukin-6 in patients with helicobacter pylori infection. Helicobacter 2016, 21, 389-394. [CrossRef]

116. Ren, L.; Zhang, J.; Reed, B.M.; Zhang, D.; Shen, X.H. Cryopreservation affects ROS-induced oxidative stress and antioxidant response in Arabidopsis seedlings. Cryobiology 2015, 79, 38-47. [CrossRef]

117. Gaschler, M.M.; Stockwell, B.R. Lipid peroxidation in cell death. Biochem. Biophys. Res. Commun. 2017, 482, 419-425. [CrossRef]

118. Abusarah, J.; Bentz, M.; Benabdoune, H.; Rondon, P.E.; Shi, Q.; Fernandes, J.C.; Fahmi, H.; Benderdour, M. An overview of the role of lipid peroxidation-derived 4-hydroxynonenal in osteoarthritis. Inflamm. Res. 2017, 66, 637-651. [CrossRef]

119. Shi, Q.; Abusarah, J.; Zaouter, C.; Moldovan, F.; Fernandes, J.C.; Fahmi, H.; Benderdour, M. New evidence implicating 4hydroxynonenal in the pathogenesis of osteoarthritis in vivo. Arthritis Rheumatol. 2014, 66, 2461-2471. [CrossRef] [PubMed]

120. Tsikas, D.; Rothmann, S.; Schneider, J.Y.; Suchy, M.T.; Trettin, A.; Modun, D.; Stuke, N.; Maassen, N.; Frölich, J.C. Development, validation and biomedical applications of stable-isotope dilution GC-MS and GC-MS/MS techniques for circulating malondialdehyde (MDA) after pentafluorobenzyl bromide derivatization: MDA as a biomarker of oxidative stress and its relation to $1 . J$ Chromatogr. B 2016, 1019, 95-111. [CrossRef]

121. Barriuso, B.; Astiasarán, I.; Ansorena, D. A review of analytical methods measuring lipid oxidation status in foods: A challenging task. Eur. Food Res. Technol. 2013, 236, 1-15. [CrossRef]

122. Reitznerová, A.; Šuleková, M.; Nagy, J.; Marcincak, S.; Semjon, B.; Certik, M.; Klempova, T. Lipid peroxidation process in meat and meat products: A comparison study of malondialdehyde determination between modified 2-thiobarbituric acid spectrophotometric method and reverse-phase high-performance liquid chromatography. Molecules 2017, 22, 1988. [CrossRef] [PubMed]

123. Malaei, R.; Ramezani, A.M.; Absalan, G. Analysis of malondialdehyde in human plasma samples through derivatization with 2,4-dinitrophenylhydrazine by ultrasound-assisted dispersive liquid-liquid microextraction-GC-FID approach. J. Chromatogr. B 2018, 1089, 60-69. [CrossRef]

124. Jafari, M.; Solhi, E.; Tagi, S.; Hasanzadeh, M.; Jouyban-Gharamaleki, V.; Jouyban, A.; Shadjou, N. Non-invasive quantification of malondialdehyde biomarker in human exhaled breath condensate using self-assembled organic-inorganic nanohybrid: A new platform for early diagnosis of lung disease. J. Pharm. Biomed. Anal. 2019, 164, 249-257. [CrossRef] [PubMed]

125. Suantawee, T.; Tantavisut, S.; Adisakwattana, S.; Tanavalee, A.; Yuktanandana, P.; Anomasiri, W.; Deepaisarnsakul, B.; Honsawek, S. Oxidative stress, vitamin E, and antioxidant capacity in knee osteoarthritis. J. Clin. Diagn. Res. 2013, 7, 1855-1859. [CrossRef] [PubMed]

126. Weber, D.; Stuetz, W.; Toussaint, O.; Debacq-Chainiauz, F.; Dolle, M.E.T.; Jansen, E.; Gonos, E.S.; Franceschi, C.; Sikora, E.; Hervonen, A. Associations between specific redox biomarkers and age in a large European cohort: The MARK-AGE Project. Oxid. Med. Cell. Longev. 2017. [CrossRef]

127. Panahi, Y.; Alishiri, G.H.; Parvin, S.; Sahebkar, A. Mitigation of systemic oxidative stress by curcuminoids in osteoarthritis: Results of a randomized controlled trial. J. Diet Suppl. 2016, 13, 209-220. [CrossRef]

128. Yang, Q.-Q.; Cheng, L.-Z.; Zhang, T.; Yaron, S.; Jiang, H.-X.; Sui, Z.-Q.; Corke, H. Phenolic profiles, antioxidant, and antiproliferative activities of turmenic (Curcuma Longa). Ind. Crop. Prod. 2020, 152. [CrossRef] 
129. Hosseinzadeh, A.; BahrampourJuybari, K.; Fatemi, M.J.; Kamarul, T.; Bagheri, A.; Tekiyehmaroof, N.; Sharifi, A.M. Protective Effect of Ginger (Zingiber officinale Roscoe) Extract against Oxidative Stress and Mitochondrial Apoptosis Induced by Interleukin$1 \beta$ in Cultured Chondrocytes. Cells Tissues Organs 2017, 204, 241-250. [CrossRef]

130. Khan, A.A.; Alsahli, M.A.; Rahmani, A.H. Myeloperoxidase as an active disease biomarker: Recent biochemical and pathological perspectives. Med. Sci. 2018, 6, 33. [CrossRef] [PubMed]

131. Kettle, A.J.; Albrett, A.M.; Chapman, A.L.; Dickerhof, N.; Forbes, L.V.; Khalilova, I.; Turner, R. Measuring chlorine bleach in biology and medicine. Biochim. Biophys. Acta 2014, 1840, 781-793. [CrossRef]

132. Aborehab, N.M.; El Bishbishy, M.H.; Refaiy, A.; Waly, N.E. A putative Chondroprotective role for IL- $1 \beta$ and MPO in herbal treatment of experimental osteoarthritis. BMC Complement. Altern. 2017, 17. [CrossRef] [PubMed]

133. Coculescu, B.I.; Dincă, G.V.; Bălăeț, C.; Manole, G.; Bălăeț, M.; Stocheci, C.M. Myeloperoxidase, a possible biomarker for the early diagnosis of cardiac diastolic dysfunction with preserved ejection fraction. J. Enzym. Inhib. Med. Chem. 2018, 33, 1292-1298. [CrossRef]

134. Cháfer-Pericás, C.; Rahkonen, L.; Sánchez-Illana, A.; Kuligowski, J.; Torres-Cuevas, I.; Cernada, M.; Cubells, E.; NuñezRamiro, A.; Andersson, S.; Vento, M.; et al. Ultra high performance liquid chromatography coupled to tandem mass spectrometry determination of lipid peroxidation biomarkers in newborn serum samples. Anal. Chim. Acta 2015, 886, 214-220. [CrossRef]

135. Milne, G.L.; Dai, Q.; Roberts, L.J. 2nd. The isoprostanes-25 years later. Biochim. Biophys. Acta 2015, 1851, 433-445. [CrossRef] [PubMed]

136. Finno, C.J.; Estell, K.E.; Winfield, L.; Katzman, S.; Bordbari, M.H.; Burns, E.N.; Miller, A.D.; Puschner, B.; Tran, C.K.; Xu, L. Lipid peroxidation biomarkers for evaluating oxidative stress in equine neuroaxonal dystrophy. J. Vet. Intern. Med. 2018, 32, 1740-1747. [CrossRef]

137. Schrumf, H.; Frobel, J.; Ostapczuk, M.S.; Krauspe, R.; Zilkens, C.; Franz, A.; Joseph, L.; Mayer, C.; Harmsen, J.-F.; Schrumf, H.; et al. The role of oxidative and nitrosative stress in the pathology of osteoarthritis: Novel candidate biomarkers for quantification of degenerative changes in the knee joint. Orthop. Rev. 2018, 10, 7460. [CrossRef]

138. Barden, A.E.; Mas, E.; Croft, K.D.; Phillips, M.; Mori, T.A. Minimizing artifactual elevation of lipid peroxidation products (F2-isoprostanes) in plasma during collection and storage. Anal. Biochem. 2014, 449, 129-131. [CrossRef]

139. Dietrich, M.; Block, G.; Benowitz, N.L.; Morrow, J.D.; Hudes, M.; Jacob, P., 3rd; Norkus, E.P.; Packer, L. Vitamin C supplementation decreases oxidative stress biomarker $\mathrm{f} 2$-isoprostanes in plasma of nonsmokers exposed to environmental tobacco smoke. Nutr. Cancer 2003, 45, 176-184. [CrossRef] [PubMed]

140. Alvarez-Suarez, J.M.; Giampieri, F.; Tulipani, S.; Casoli, T.; Di Stefano, G.; González-Paramás, A.M.; Santos-Buelga, C.; Busco, F.; Quiles, J.L.; Cordero, M.D.; et al. One-month strawberry-rich anthocyanin supplementation ameliorates cardiovascular risk, oxidative stress markers and platelet activation in humans. J. Nutr. Biochem. 2014, 25, 289-294. [CrossRef] [PubMed]

141. Barreiro, E. Role of protein carbonylation in skeletal muscle mass loss associated with chronic conditions. Proteomes 2016, 4, 18. [CrossRef]

142. Song, Y.R.; Kim, J.K.; Lee, H.S.; Kim, S.G.; Choi, E.K. Serum levels of protein carbonyl, a marker of oxidative stress, are associated with overhydration, sarcopenia and mortality in hemodialysis patients. BMC Nephrol. 2020, 21, 281. [CrossRef]

143. Almogbel, E.; Rasheed, N. Protein mediated oxidative stress in patients with diabetes and its associated neuropathy: Correlation with protein carbonylation and disease activity markers. J. Clin. Diagn. Res. 2017, 11, BC21-BC25. [CrossRef]

144. Pullaiah, P.; Suchitra, M.M.; Siddhartha Kumar, B. Protein carbonyls and protein thiols in rheumatoid arthritis. Int. J. Res. Med. Sci. 2018, 6, 1738-1741. [CrossRef]

145. Costa, N.A.; Gut, A.L.; Azevedo, P.S.; Tanni, S.E.; Cunha, N.B.; Fernandes, A.A.H.; Polegato, B.F.; Zornoff, L.A.M.; de Paiva, S.A.R.; Balbi, A.L. Protein carbonyl concentration as a biomarker for development and mortality in sepsis-induced acute kidney injury. Biosci. Rep. 2018, 38, BSR20171238. [CrossRef] [PubMed]

146. Ba, X.; Aguilera-Aguirre, L.; Rashid, Q.T.; Bacsi, A.; Radak, Z.; Sur, S.; Hosoki, K.; Hegde, M.L.; Boldogh, I. The role of 8-oxoguanine DNA glycosylase-1 in inflammation. Int. J. Mol. Sci. 2014, 15, 16975-16997. [CrossRef]

147. Zhang, L.; Dong, X.; Lee, M.; Maslov, A.Y.; Wang, T.; Vijg, J. Single-cell whole-genome sequencing reveals the functional landscape of somatic mutations in B lymphocytes across the human lifespan. Proc. Natl. Acad. Sci. USA 2019, 116, 9014-9019. [CrossRef]

148. den Hollander, W.; Meulenbelt, I. DNA methylation in osteoarthritis. Curr. Genomics 2015, 16, 419-426. [CrossRef] [PubMed]

149. Bae, T.; Tomasini, L.; Mariani, J.; Zhou, B.; Roychowdhury, T.; Franjic, D.; Pletikos, M.; Pattni, R.; Chen, B.J.; Venturini, E.; et al. Different mutational rates and mechanisms in human cells at pregastrulation and neurogenesis. Science 2018, 359, 550-555. [CrossRef]

150. Franco, I.; Johansson, A.; Olsson, K.; Vrtacnik, P.; Lundin, P.; Helgadottir, H.T.; Larsson, M.; Revenchon, G.; Bosia, C.; Pagnani, A. Somatic mutagenesis in satellite cells associates with human skeletal muscle aging. Nat. Commun. 2018, 9, 800. [CrossRef]

151. Ferrucci, L.; Gonzalez-Freire, M.; Fabbri, E.; Simonsck, E.; Tanaka, T.; Moore, Z.; Salimi, S.; Sierra, F.; de Cabo, R. Measuring biological aging in humans: A quest. Aging Cell 2020, 19, e13080. [CrossRef] [PubMed]

152. Broedbaek, K.; Siersma, V.; Henriksen, T.; Weimann, A.; Petersen, M.; Andersen, J.T.; Jimenez-Solem, E.; Hansen, L.J.; Henriksen, J.E.; Bonnema, S.J.; et al. Urinary markers of nucleic acid oxidation and cancer in type 2 diabetes. Redox Biol. 2015, 4, 34-39. [CrossRef] 
153. Al-Salmani, K.; Abbas, H.H.; Schulpen, S.; Karbaschi, M.; Abdalla, I.; Bowman, K.J.; So, K.K.; Evans, M.D.; Jones, G.D.; Godschalk, R.W.; et al. Simplified method for the collection, storage, and comet assay analysis of DNA damage in whole blood. Free Radic. Biol. Med. 2011, 51, 719-725. [CrossRef]

154. Fernandez-Moreno, M.; Soto-Hermida, A.; Pertega, S.; Oreiro, N.; Fernandez-Lopez, C.; Rego-Perez, I.; Blanco, F.J. Mitochondrial DNA (mtDNA) haplogroups and serum levels of anti-oxidant enzymes in patients with osteoarthritis. BMC Musculoskelet. Disord. 2011, 12. [CrossRef]

155. Marrocco, I.; Altieri, F.; Peluso, I. Measurement and clinical significance of biomarkers of oxidative stress in humans. Oxid. Med. Cell. Longev. 2017. [CrossRef]

156. Lettieri-Barbato, D.; Tomei, F.; Sancini, A.; Morabito, G.; Serafini, M. Effect of plant foods and beverages on plasma non-enzymatic antioxidant capacity in human subjects: A meta-analysis. Br. J. Nutr. 2013, 109, 1544-1556. [CrossRef]

157. Peluso, I.; Raguzzini, A. Salivary and urinary total antioxidant capacity as biomarkers of oxidative stress in humans. Pathol. Res. Int. 2016. [CrossRef] [PubMed]

158. Bartosz, G. Non-enzymatic antioxidant capacity assays: Limitations of use in biomedicine. Free Radic. Res. 2010, 44, 711-720. [CrossRef] [PubMed]

159. Niki, E. Assessment of antioxidant capacity in vitro and in vivo. Free Radic. Biol. Med. 2010, 49, 503-515. [CrossRef]

160. Hantikainen, E.; Grotta, A.; Serafini, M.; TrolleLagerros, Y.; Nyren, O.; Ye, W.; Colarusso, L.; Bellocco, R. Dietary non-enzymatic antioxidant capacity and the risk of myocardial infarction: The Swedish National March Cohort. Int. J. Epidemiol. 2018, 47, 1947-1955. [CrossRef]

161. Bastani, A.; Rajabi, S.; Daliran, A.; Saadat, H.; Karimi-Busheri, F. Oxidant and antioxidant status in coronary artery disease. Biomed. Rep. 2018, 9, 327-332. [CrossRef] [PubMed]

162. Bagherifard, A.; Kadijani, A.A.; Yahyazadeh, H.; Rezazadeh, J.; Azizi, M.; Akbari, A.; Mirzae, A. The value of serum total oxidant to the antioxidant ratio as a biomarker of knee osteoarthritis. Clin. Nutr. ESPEN 2020, 38, 118-123. [CrossRef] [PubMed]

163. Koike, M.; Nojiri, H.; Kanazawa, H.; Yamaguchi, H.; Miyagawa, K.; Nagura, N.; Banno, S.; Iwase, Y.; Kurosawa, H.; Kaneko, K. Superoxide dismutase activity is significantly lower in end-stage osteoarthritic cartilage than non-osteoarthritic cartilage. PLoS ONE 2018, 13. [CrossRef] [PubMed]

164. Li, S.; Yang, X.; Feng, Z.; Wang, P.; Zhu, W.; Cui, S. Catalase enhances viability of human chondrocytes in culture by reducing reactive oxygen species and counteracting tumor necrosis factor- $\alpha$-induced apoptosis. Cell. Physiol. Biochem. 2018, 49, 2427-2442. [CrossRef]

165. Gheita, T.A.; Kenawy, S.A. Measurement of malondialdehyde, glutathione, and glutathione peroxidase in SLE patients. Methods Mol. Biol. 2014, 1134, 193-199. [CrossRef]

166. Amzoiu, D.C.; Pisoschi, C.G.; Stoian Bulearcă, A.M.; Rău, G. Blood glutathione peroxidase activity in patients with osteoarthritis treated with oxicams. Curr. Heal. Sci. J. 2016, 42, 29-34. [CrossRef]

167. Sentellas, S.; Morales-Ibanez, O.; Zanuy, M.; Albertí, J.J. GSSG/GSH ratios in cryopreserved rat and human hepatocytes as a biomarker for drug induced oxidative stress. Toxicol. Vitr. 2014, 28, 1006-1015. [CrossRef]

168. Xie, L.Q.; Lin, A.S.P.; Kundu, K.; Levenston, M.E.; Murthy, N.; Guldberg, R.E. Quantitative imaging of cartilage and bone morphology, reactive oxygen species, and vascularization in a rodent model of osteoarthritis. Arthritis Rheumatol. 2012, 64, 1899-1908. [CrossRef]

169. Paździor, M.; Kiełczykowska, M.; Kurzepa, J.; Luchowska-Kocot, D.; Kocot, J.; Musik, I. The oxidative stress in knee osteoarthritis patients. An attempt of evaluation of possible compensatory effects occurring in the disease development. Medicina 2019, 55, 150. [CrossRef]

170. Ullevig, S.L.; Kim, H.S.; Short, J.D.; Tavakoli, S.; Weintraub, S.T.; Downs, K.; Asmis, R. Protein S-Glutathionylation mediates macrophage responses to metabolic cues from the extracellular environment. Antioxid. Redox Signal. 2016, 25, 836-851. [CrossRef]

171. Hung, M.; Bounsanga, J.; Voss, M.W.; Gu, Y.; Crum, A.B.; Tang, P. Dietary and supplemental vitamin C and D on symptom severity and physical function in knee osteoarthritis. J. Nutr. Gerontol. Geriatr. 2017, 36, 121-133. [CrossRef]

172. Heidar, E.H.; Al Faya, F.; Hassan, W.N.; Eid, R.A.; Haidara, M.A. The impact of antioxidants on inflammation and oxidative stress markers in osteoarthritis rat model: Scanning electron microscope insights. Am. J. Pharmacol. Toxicol. 2014, 9, 157-167. [CrossRef]

173. Wojdasiewicz, P.; Poniatowski, L.A.; Szukiewicz, D. The role of inflamatory and anti-inflammatory cytokines in the pathogenesis of osteoarthritis. Mediat. Inflamm. 2014. [CrossRef] [PubMed]

174. Limagne, E.; Lançon, A.; Delmas, D.; Cherkaoui-Malki, M.; Latruffe, N. Resveratrol interferes with IL1- $\beta$-induced proinflammatory paracrine interaction between primary chondrocytes and macrophages. Nutrients 2016, 8, 280. [CrossRef] [PubMed]

175. Grover, A.K.; Samson, S.E. Benefits of antioxidant supplements for knee osteoarthritis: Rationale and reality. Nutr. J. 2015, 15, 1475-2891. [CrossRef] [PubMed]

176. Xu, D.P.; Li, Y.; Meng, X.; Zhou, T.; Zhou, Y.; Zheng, J.; Zhang, J.J.; Li, H.B. Natural antioxidants in foods and medicinal plants: Extraction, assessment and resources. Int. J. Mol. Sci. 2017, 18, 96. [CrossRef]

177. Zhao, B.; Zhao, P.; Jin, Z.; Fan, M.; Meng, J.; He, Q. Programmed ROS/CO-releasing nanomedicine for synergetic chemodynamicgas therapy of cancer. J. Nanobiotechnology 2019, 17. [CrossRef] [PubMed]

178. Turin-Moleavin, I.A.; Fifere, A.; Lungoci, A.L.; Rosc, I.; Coroaba, A.; Dragos, P.; Pasca, S.A.; Bostanaru, A.C.; Mares, M.; Pinteala, M. In Vitro and in vivo antioxidant activity of the new magnetic-cerium oxide nanoconjugates. Nanomaterials 2019, 9, 1565. [CrossRef] 
179. Gonzalez-Rodríguez, M.L.; Fernandez-Romero, A.M.; Rabasco, A.M. Towards the antioxidant therapy in Osteoarthritis: Contribution of nanotechnology. J. Drug Deliv. Sci. Technol. 2017, 42, 94-106. [CrossRef]

180. Pradal, J.; Jordan, O.; Allemann, E. Intra-articular drug delivery for arthritis diseases: The value of extended release and targeting strategies. J. Drug Deliv. Sci. Techol. 2012, 22, 409-410. [CrossRef]

181. Yu, S.P.; Hunter, D.J. Intra-articular therapies for osteoarthritis. Expert Opin. Pharmacother. 2016, 17, 2057-2071. [CrossRef]

182. Lungoci, A.L.; Turin-Moleavin, I.A.; Corciova, A.; Mircea, C.; Arvinte, A.; Fifere, A.; Marangoci, N.L.; Pinteala, M. Multifunctional magnetic cargo-complexes with radical scavenging properties. Mater. Sci. Eng. C Mater. Biol. Appl. 2019, 94, 608-618. [CrossRef]

183. Kang, C.; Jung, E.; Hyeon, H.; Seon, S.; Lee, D. Acid-activatable polymeric curcumin nanoparticles as therapeutic agents for osteoarthritis. Nanomedicine 2020, 23, 102104. [CrossRef] [PubMed]

184. Mohammadifar, M.; Aarabi, M.H.; Aghighi, F.; Kazemi, M.; Vakili, Z.; Mohammad Reza Memarzadeh, M.R.; Sayyed Alireza Tala, S.A. Anti-osteoarthritis potential of peppermint and rosemary essential oils in a nanoemulsion form: Behavioral, biochemical, and histopathological evidence. BMC Complement. Med. Ther. 2021, 21, 57. [CrossRef] [PubMed]

185. Veselack, T.; Aldebert, G.; Trunfio-Sfarghiu, A.M.; Schmid, T.M.; Laurent, M.P.; Wimmer, M.A. Phospholipid vesicles in media for tribological studies against live cartilage. Lubricants 2018, 6, 19. [CrossRef]

186. Day, A.J.; Canada, F.J.; Diaz, J.C.; Kroon, P.A.; Mclauchlan, R.; Faulds, C.B.; Plumb, G.W.; Morgan, M.R.A.; Williamson, G. Dietary flavonoid and isofavone glycosides are hydrolysed by the lactase site of lactase phlorizin hydrolase. FEBS Lett. 2000, 468, 166-170. [CrossRef]

187. Spencer, J.P.E.; Chowrimootoo, G.; Choudhury, R.; Debnam, E.S.; Srai, S.K.; Rice-Evans, C. The small intestine can both absorb and glucuronidate luminal flavonoids. FEBS Lett. 1999, 458, 224-230. [CrossRef]

188. Hollman, P.C.H.; Katan, M.B. Absorption, metabolism and bioavailability of flavonoids. In Flavonoids in Health and Disease; Rice Evans, C., Packer, L., Eds.; Marcel Dekker Inc: New York, NY, USA, 1998.

189. Kuhnle, G.; Spencer, J.P.E.; Schroeter, H.; Shenoy, B.; Debnam, E.S.; Srai, S.K.S.; Rice-Evans, C.; Hahn, U. Epicatechin and catechin are o-methylated and glucuronidated in the small intestine. Biochem. Biophys. Res. Commun. 2000, 277, 507-512. [CrossRef]

190. Aura, A.M.; O’Leary, K.A.; Williamson, G.; Ojala, M.; Bailey, M.; Puupponen-Pimia, R.; Nuutila, A.M.; Oksman Caldentey, K.M.; Poutanen, K.; Bailey, M.; et al. Quercetin derivatives are deconjugated and converted to hydroxyphenylacetic acids but not methylated by human fecal flora in vitro. J. Agric. Food Chem. 2002, 50, 1725-1730. [CrossRef] [PubMed]

191. Da Silva, E.L.; Piskula, M.K.; Yamamoto, N.; Moon, J.H.; Terao, J. Quercetin metabolites inhibit copper ion-induced lipid peroxidation in rat plasma. FEBS Lett. 1998, 430, 405-408. [CrossRef]

192. Yamamoto, N.; Moon, J.H.; Tsushida, T.; Nagao, A.; Terao, J. Inhibitory effect of quercetin metabolites and their related derivatives on copper ion-induced lipid peroxidation in human low-density lipoprotein. Arch. Biochem. Biophys. 1999, 372, 347-354. [CrossRef] [PubMed]

193. Moon, J.H.; Tsushida, T.; Nakahara, K.; Terao, J. Identification of quercetin 3-O-beta-D-glucuronide as an antioxidative metabolite in rat plasma after oral administration of quercetin. Free Radic. Biol. Med. 2001, 30, 1274-1285. [CrossRef]

194. Morand, C.; Crespy, V.; Manach, C.; Besson, C.; Demigne, C.; Remesy, C. Plasma metabolites of quercetin and their antioxidant properties. Am. J. Physiol. 1998, 275, 212-219. [CrossRef]

195. Valentová, K.; Káňová, K.; Di Meo, F.; Pelantová, H.; Chambers, C.S.; Rydlová, L.; Petrásková, L.; Křenková, A.; Cvačka, J.; Trouillas, P.; et al. Chemoenzymatic preparation and biophysical properties of sulfated quercetin. Metab. Int. J. Mol. Sci. 2017, 18, 2231. [CrossRef] [PubMed]

196. Manach, C.; Morand, C.; Crespy, V.; Demigne, C.; Texier, O.; Regerat, F.; Remesy, C. Quercetin is recovered in human plasma as conjugated derivatives which retain antioxidant properties. FEBS Lett. 1998, 426, 331-336. [CrossRef]

197. Wei, B.; Zhang, Y.; Tang, L.; Ji, Y.; Yan, C.; Zhang, X. Protective effects of quercetin against inflammation and oxidative stress in a rabbit model of knee osteoarthritis. Drug Dev. Res. 2019, 1-8. [CrossRef] [PubMed]

198. Springer, M.; Moco, S. Resveratrol and its human metabolites-effects on metabolic health and obesity. Nutrients 2019, 11, 143. [CrossRef]

199. Olthof, M.R.; Hollman, P.C.H.; Katan, M.B. Chlorogenic acid and caffeic acid are absorbed in humans. J. Nutr. 2001, 131, 66-71. [CrossRef]

200. Clifford, M.N.; Kerimi, A.; Williamson, G. Bioavailability and metabolism of chlorogenic acids (acyl-quinic acids) in humans. Compr. Rev. Food Sci. Food. Saf. 2020, 1-54. [CrossRef]

201. Farah, A.; Duarte, G. Coffee in health and disease prevention. In Coffee in Health and Disease Prevention; Preedy, V., Ed.; Academic Press: Cambrigde, MA, USA, 2015; pp. 789-801.

202. De Bock, M.; Thorstensen, E.B.; Derraik, J.G.B.; Henderson, H.V.; Hofman, P.L.; Cutfield, W.S. Human absorption and metabolism of oleuropein and hydroxytyrosol ingested as olive (Olea europaeaL.) leaf extract. Mol. Nutr. Food Res. 2013, 57, $2079-2085$. [CrossRef]

203. Tuck, K.L.; Hayball, P.J.; Stupans, I. Structural characterization of the metabolites of hydroxytyrosol, the principal phenolic component in olive oil, in rats. J. Agric. Food Chem. 2002, 50, 2404-2409. [CrossRef] [PubMed]

204. Lopez de las Hazas, M.C.; Pinol, C.; Macia, A.; Romero, M.P.; Pedret, A.; Sola, R.; Motilva, M.J. Differential absorption and metabolism of hydroxytyrosol and its precursors oleuropein and secoiridoids. J. Funct. Foods 2016, 22, 52-63. [CrossRef]

205. Noce, A.; Marrone, G.; Di Daniele, F.; Ottaviani, E.; Wilson Jones, G.; Bernini, R.; Romani, A.; Rovella, V. Impact of gut microbiota composition on onset and progression of chronic non-communicable diseases. Nutrients 2019, 11, 1073. [CrossRef] 
206. Mosele, J.I.; Martin-Pelaez, S.; Macia, A.; Farras, M.; Valls, R.M.; Catalan, U.; Motilva, M.J. Faecal microbial metabolism of olive oil phenolic compounds: In vitro and in vivo approaches. Mol. Nutr. Food Res. 2014, 58, 1809-1819. [CrossRef]

207. Horcajada, M.N.; Beaumont, M.; Sauvageot, N.; Poquet, L.; Saboundjian, M.; Hick, A.C.; Costes, B.; Garcia, L.; Henrotin, Y. An oleuropein-based dietary supplement improves joint functionality in older people with high knee joint pain. Osteoarthr. Cart. 2020, 28. [CrossRef]

208. Miyazawa, T. Absorption, metabolism and antioxidative effects of tea catechin in humans. BioFactors 2000, 13, 55-59. [CrossRef] [PubMed]

209. Lee, M.J.; Maliakal, P.; Chen, L.; Meng, X.; Bondoc, F.Y.; Prabhu, S.; Lambert, G.; Mohr, S.; Yang, C.S. Pharmacokinatics of tea cathechins after ingestion of green tea and (-) epigallocatechin-3- gallate by humans. Cancer Epidemiol. Biomark. Prov. 2002, $11,1025-1032$

210. Umegaki, K.; Sugisawa, A.; Yamada, K.; Higuchi, M. Analytical method of measuring tea cathechins in human plasma by solid-phase extraction and HPLC with electrochemical detection. J. Nutr. Sci. Vitaminol. 2001, 47, 402-408. [CrossRef]

211. Feng, W.Y. Metabolism of green tea catechins. Curr. Drug Metab. 2006, 7, 755-809. [CrossRef]

212. Zeng, J.; Wang, H.; Shen, Z.; Yao, X.; Wu, C.; Pan, T. Curcumin inhibits proliferation of synovial cells by downregulating expression of matrix metalloproteinase-3 in osteoarthritis. Orthop. Surg. 2019, 11, 117-125. [CrossRef]

213. Dei Cas, M.; Ghidoni, R. Dietary curcumin: Correlation between bioavailability and health potential. Nutrients 2019, 11, 2147. [CrossRef]

214. Pandey, A.; Chaturvedi, M.; Mishra, S.; Kumar, P.; Somvanshi, P.; Chaturvedi, R. Reductive metabolites of curcumin and their therapeutic effects. Heliyon 2020, 6. [CrossRef] [PubMed]

215. Henrotin, Y.; Priem, F.; Mobasheri, A. Curcumin: A new paradigm and therapeutic opportunity for the treatment of osteoarthritis: Curcumin for osteoarthritis management. Springerplus 2013, 2. [CrossRef]

216. Feng, Z.; Li, X.; Lin, J.; Zheng, W.; Hu, Z.; Xuan, J.; Ni, W.; Pan., X. Oleuropein inhibits the IL-1 $\beta$-induced expression of inflammatory mediators by suppressing the activation of NF-kB and MAPKs in human osteoarthritis chondrocytes. Food Funct. 2017, 8, 3737-3744. [CrossRef]

217. Wang, J.; Gao, J.S.; Chen, J.W.; Li, F.; Tian, J. Effect of resveratrol on cartilage protection and apoptosis inhibition in experimental osteoarthritis of rabbit. Rheumatol. Int. 2012, 32, 1541-1548. [CrossRef]

218. Liu, L.; Gu, H.; Liu, H.; Jiao, Y.; Li, K.; Zhao, Y.; An, L.; Yang, J. Protective effect of resveratrol against IL-1 $\beta$-induced inflammatory response on human osteoarthritic chondrocytes partly via the TLR4/MyD88/NF-kB signaling pathway: An "in vitro study". Int. J. Mol. Sci. 2014, 15, 6925-6940. [CrossRef]

219. Chen, W.P.; Tang, J.L.; Bao, J.P.; Hu, P.F.; Shi, Z.L.; Wu, L.-D. Anti-arthritic effects of chlorogenic acid in interleukin-1 $\beta$-induced rabbit chondrocytes and a rabbit osteoarthritis model. Int. Immunopharmacol. 2011, 11, 23-28. [CrossRef] [PubMed]

220. Ahmed, S.; Rahman, A.; Hasnain, A.; Lalonde, M.; Goldberg, V.M.; Haqqi, T.M. Green tea polyphenol epigallocatechin-3-gallate inhibits the IL-1 $\beta$-induced activity and expression of cyclooxygenase- 2 and nitric oxide synthase- 2 in human chondrocytes. Free Radic. Biol. Med. 2002, 33, 1097-1105. [CrossRef]

221. Wandel, S.; Jüni, P.; Tendal, B.; Nüesch, E.; Villiger, P.M.; Welton, N.J.; Reichenbach, S.; Trelle, S. Efects of glucosamine, chondroitin, or placebo in patients with osteoarthritis of hip or knee: Network meta-analysis. BMJ 2010, 341, c4675. [CrossRef] [PubMed]

222. Reginster, J.Y.; Altman, R.D.; Hochberg, M.C. Prescription glucosamine sulphate is effective in knee osteoarthritis. BMJ 2010, 9, c6335. [CrossRef]

223. Pavelká, K.; Gatterová, J.; Olejarová, M.; Machacek, S.; Giacovelli, G.R.L. Glucosamine sulfate use and delay of progression of knee osteoarthritis: A 3-year, randomized, placebo-controlled, double-blind study. Arch. Intern. Med. 2002, 162, $2113-2123$. [CrossRef] [PubMed]

224. Lee, C.J.; Chen, L.G.; Liang, W.L.; Hsieh, M.S.; Wang, C.C. Inhibitory effects of punicalagin from Punica granatum against type II collagenase-induced osteoarthritis. J. Funct. Foods 2018, 41, 216-222. [CrossRef]

225. Chen, W.P.; Jin, G.J.; Xiong, Y.; Hu, P.F.; Bao, J.P.; Wu, L.D. Rosmarinic acid down-regulates NO and PGE 2 expression via MAPK pathway in rat condrocites. J. Cell. Mol. Med. 2018, 22, 346-353. [CrossRef] [PubMed]

226. Valentová, K. Cytoprotective activity of natural and synthetic antioxidants. Antioxidants 2020, 9, 713. [CrossRef]

227. Deligiannidou, G.E.; Papadopoulos, R.E.; Kontogiorgis, C.; Detsi, A.; Bezirtzoglou, E. Unraveling Natural Products' Role in Osteoarthritis Management-An Overview. Antioxidants 2020, 9, 348. [CrossRef]

228. Yang, Y.; Su, Y.; Wang, D.; Chen, Y.; Wu, T.; Li, G.; Sun, X.; Cui, L. Tanshinol attenuates the deleterious effects of oxidative stress on osteoblastic differentiation via Wnt/FoxO3a signaling. Oxid. Med. Cell. Longev. 2013. [CrossRef]

229. Vester, H.; Holzer, N.; Neumaier, M.; Lilianna, S.; Nüssler, A.K.; Seeliger, C. Green Tea Extract (GTE) improves differentiation in human osteoblasts during oxidative stress. J. Inflamm. 2014, 11. [CrossRef]

230. Basu, A.; Kurien, B.T.; Tran, H. Strawberries decrease circulating levels of tumor necrosis factor and lipid peroxides in obese adults with knee osteoarthritis. Food Funct. 2018, 9, 6218-6226. [CrossRef]

231. Figueira, M.E.; Câmara, M.B.; Direito, R.; Rocha, J.; Serra, A.T.; Duarte, C.M.M.; Fernandes, A.; Freitas, M.; Fernandes, E.; Marques, M.C.; et al. Chemical characterization of a red raspberry fruit extract and evaluation of its pharmacological effects in experimental models of acute inflammation and collagen-induced arthritis. Food Funct. 2014, 5, 3241-3251. [CrossRef] 
232. Figueira, M.E.; Oliveira, M.; Direito, R.; Rocha, J.; Alves, P.; Serra, A.T.; Duarte, C.; Bronze, R.; Fernandes, A.; Brites, D.; et al. Protective effects of a blueberry extract in acute inflammation and collagen-induced arthritis in the rat. Biomed. Pharmacother. 2016, 83, 1191-1202. [CrossRef]

233. Silva, P.; Sureda, A.; Tur, J.A.; Andreoletti, P.; Cherkaoui-Malki, M.; Latruffe, N. How efficient is resveratrol as an antioxidant of the Mediterranean diet, towards alterations during the aging process? Free Radic. Res. 2019, 53, 1101-1112. [CrossRef] [PubMed]

234. Li, W.; Cai, L.; Zhang, Y.; Cui, L.; Shen, G. Intra-articular resveratrol injection preventsosteoarthritis progression in a mouse model by activating SIRT1 and thereby silencing HIF-2 $\alpha$. J. Orthop. Res. 2015, 33, 1061-1070. [CrossRef]

235. Fernandes, I.; Pérez-Gregorio, R.; Soares, S.; Mateus, N.; de Freitas, V. Wine flavonoids in health and disease prevention. Molecules 2017, 22, 292. [CrossRef] [PubMed]

236. Tatullo, M.; Simone, G.M.; Tarullo, F.; Irlandese, G.; Vito, D.d.; Marrelli, M.; Santacroce, L.; Cocco, T.; Ballini, A.; Scacco, S. Antioxidant and antitumor activity of a bioactive polyphenolic fraction isolated from the brewing process. Sci. Rep. 2016, 6 . [CrossRef]

237. Hermans, N.; Steenput, B.; Roth, L.; Meyer, G.D.; Santos, C.N.d.; Valentová, K.; Dambrova, M.; Bruyne, T.D. Protective effects of dietary polyphenols on arterial stiffness. Proceedings 2019, 11, 1040. [CrossRef]

238. Leyva-López, N.; Gutierrez-Grijalva, E.P.; Ambriz-Perez, D.L.; Heredia, J.B. Flavonoids as cytokine modulators: A possible therapy for inflammation-related diseases. Int. J. Mol. Sci. 2016, 17, 921. [CrossRef]

239. Ghoochani, N.; Karandish, M.; Mowla, K.; Haghighizadeh, M.H.; Jalali, M.T. The effect of pomegranate juice on clinical signs, matrix metalloproteinases and antioxidant status in patients with knee osteoarthritis. J. Sci. Food. Agric. 2016, 96, 4377-4381. [CrossRef] [PubMed]

240. Khadem Haghighian, M.; Alipoor, B.; Eftekhar Sadat, B.; Malek Mahdavi, A.; Moghaddam, A.; Vatankhah, A.M. Effects of sesame seed supplementation on lipid profile and oxidative stress biomarkers in patients with knee osteoarthritis. Health Promot. Perspect. 2014, 4, 90-97. [CrossRef] [PubMed]

241. Dehghani, S.; Alipoor, E.; Salimzadeh, A.; Yaseri, M.; Hosseini, M.; Feinle-Bisset, C.; Hosseinzadeh-Attar, M.J. The effect of a garlic supplement on the pro-inflammatory adipocytokines, resistin and tumor necrosis factor-alpha, and on pain severity, in overweight or obese women with knee osteoarthritis. Phytomedicine 2018, 48, 70-75. [CrossRef]

242. Christiansen, B.A.; Bhatti, S.; Goudarzi, R.; Emami, S. Management of osteoarthritis with avocado/soybean unsaponifiables. Cartilage 2015, 6, 30-44. [CrossRef]

243. Veronese, N.; Koyanagi, A.; Stubbs, B.; Cooper, C.; Guglielmi, G.; Rizzoli, R.; Punzi, L.; Rogoli, D.; Caruso, M.G.; Rotolo, O.; et al. Mediterranean diet and knee osteoarthritis outcomes: A longitudinal cohort study. Clin. Nutr. 2019, 38, 2735-2739. [CrossRef]

244. Musumeci, G.; Trovato, F.M.; Pichler, K.; Weinberg, A.M.; Loreto, C.; Castrogiovanni, P. Extra-virgin olive oil diet and mild physical activity prevent cartilage degeneration in an osteoarthritis model: An in vivo and in vitro study on lubricin expression. J. Nutr. Biochem. 2013, 24, 2064-2075. [CrossRef] [PubMed]

245. Takuma, M.; Haruka, K.; Mutsuto, W.; Toshiki, M.; Kenshiro, M.; Akane, T.; Hiroshi, M.; Yoshihiro, N. Olive leaf extract prevents cartilage degeneration in osteoarthritis of STR/ort mice. Biosci. Biotechnol. Biochem. 2018, 82, 1101-1106. [CrossRef] [PubMed]

246. Horcajada, M.N.; Sanchez, C.; Membrez Scalfo, F.; Drion, P.; Comblain, F.; Taralla, S.; Donneau, A.F.; Offord, E.A.; Henrotin, Y. Oleuropein or rutin consumption decreases the spontaneous development of osteoarthritis in the Hartley guinea pig. Osteoar. Cart. 2015, 23, 94-102. [CrossRef]

247. Messina, O.D.; Vidal Wilman, M.; Vidal Neira, L.F. Nutrition, osteoarthritis and cartilage metabolism. Aging. Clin. Exp. Res. 2019, 31, 807-813. [CrossRef] [PubMed]

248. Vaishya, R.; Agarwal, A.K.; Shah, A.; Vijay, V.; Vaish, A. Current status of top 10 nutraceuticals used for knee osteoarthritis in India. J. Clin. Orthop. Trauma 2018, 9, 338-348. [CrossRef]

249. Rondanelli, M.; Miraglia, N.; Putignano, P.; Peroni, G.; Faliva, M.A.; Naso, M.; Gasparri, C.; Infantino, V.; Nichetti, M.; Volpi, N.; et al. Short-and long term effectiveness of supplementation with non-animal chondroitin sulphate on inflammation, oxidative stress and functional status in obese subjects with moderate knee osteoarthritis before and after physical stress: A randomized, double-bl. Antioxidants 2020, 9, 1241. [CrossRef]

250. Xing, R.; Liu, S.; Guo, Z.; Yu, H.; Li, C.; Ji, X.; Feng, J.; Li, P. The antioxidant activity of glucosamine hydrochloride in vitro. Bioorg. Med. Chem. 2006, 14, 1706-1709. [CrossRef]

251. Campo, G.M.; Avenoso, A.; Campo, S.; Ferlazzo, A.M.; Calatroni, A. Chondroitin sulphate: Antioxidant properties and beneficial effects. Mini Rev. Med. Chem. 2006, 6, 1311-1320. [CrossRef]

252. Campo, G.M.; Avenoso, A.; Campo, S.; D'Ascola, A.; Traina, P.; Calatroni, A. Chondroitin-4-sulphate inhibits NF-kB translocation and caspase activation in collagen-induced arthritis in mice. Osteoarthrs. Cart. 2008, 16, 1474-1483. [CrossRef]

253. Campo, G.M.; Avenoso, A.; Campo, S.; Ferlazzo, A.M.; Calatroni, A. Antioxidant activity of chondroitin sulfate. Adv. Pharmacol. 2006, 53, 417-431. [CrossRef] [PubMed]

254. Kucharz, E.J.; Kovalenko, V.; Szántó, S.; Bruyère, O.; Cooper, C.; Reginster, J.Y. A review of glucosamine for knee osteoarthritis: Why patented crystalline glucosaminesulfate should be differentiated from other glucosamines to maximize clinical outcomes. Curr. Med. Res. Opin. 2016, 32. [CrossRef] [PubMed]

255. Kuptniratsaikul, V.; Dajpratham, P.; Taechaarpornkul, W.; Buntragulpoontawee, M.; Lukkanapichonchut, P.; Chootip, C.; Saengsuwan, J.; Tantayakom, K.; Laongpech, S. Efficacy and safety of Curcuma domestica extracts compared with ibuprofen in patients with knee osteoarthritis: A multicenter study. Clin. Interv. Aging. 2014, 9, 451-458. [CrossRef] [PubMed] 
256. Lee, D.; Bamdad, F.; Khey, K.; Sunwoo, H.H. Antioxidant and anti-inflammatory properties of chicken egg vitelline membrane hydrolysates. Poult. Sci. 2017, 96, 3510-3516. [CrossRef]

257. Feng, P.; Ding, H.; Lin, H.; Chen, W. AOD: The antioxidant protein database. Sci Rep 2017, 17. [CrossRef]

258. Chovanová, K.; Böhmer, M.; Poljovka, A.; Budiš, J.; Harichová, J.; Szemeš, T.; Zámocký, M. Parallel molecular evolution of catalases and superoxide dismutases-focus on thermophilic fungal genomes. Antioxidants 2020, 9, 1047. [CrossRef]

259. Han, H.; Ling, Z.; Khan, A.; Virk, A.K.; Kulshrestha, S.; Li, X. Improvements of thermophilic enzymes: From genetic modifications to applications. Bioresour. Technol. 2019, 279, 350-361. [CrossRef]

260. Lee, D.Y.; Park, Y.J.; Song, M.G.; Kim, D.R.; Zada, S.; Kim, D.H. Cytoprotective effects of delphinidin for human chondrocytes against oxidative stress through activation of autophagy. Antioxidants 2020, 9, 83. [CrossRef]

261. Nitoi, L.C.; Ardeleanu, V.; Stoian, A.P.; Moroianu, L.A. Correlation between body composition analysis and biochemical nutritional markers in maintenance hemodialysis patients with chronic liver disease. Rev. Chim. 2020, 71, 94-100. [CrossRef] 